\title{
Understanding the impact of recent advances in isoprene photooxidation on simulations of regional air quality
}

\author{
Y. Xie ${ }^{1}$, F. Paulot ${ }^{2, *}$, W. P. L. Carter ${ }^{3}$, C. G. Nolte ${ }^{1}$, D. J. Luecken ${ }^{1}$, W. T. Hutzell ${ }^{1}$, P. O. Wennberg ${ }^{2}$, R. C. Cohen ${ }^{4}$, and \\ R. W. Pinder ${ }^{1}$ \\ ${ }^{1}$ US EPA Office of Research and Development, Durham, North Carolina, USA \\ ${ }^{2}$ California Institute of Technology, Pasadena, California, USA \\ ${ }^{3}$ University of California, Riverside, Riverside, California, USA \\ ${ }^{4}$ University of California, Berkeley, Berkeley, California, USA \\ *now at: Harvard University, Cambridge, Massachusetts, USA
}

Correspondence to: R. W. Pinder (pinder.rob@epa.gov)

Received: 5 September 2012 - Published in Atmos. Chem. Phys. Discuss.: 17 October 2012

Revised: 26 January 2013 - Accepted: 12 July 2013 - Published: 27 August 2013

\begin{abstract}
The CMAQ (Community Multiscale Air Quality) us model in combination with observations for INTEX-NA/ICARTT (Intercontinental Chemical Transport Experiment-North America/International Consortium for Atmospheric Research on Transport and Transformation) 2004 are used to evaluate recent advances in isoprene oxidation chemistry and provide constraints on isoprene nitrate yields, isoprene nitrate lifetimes, and $\mathrm{NO}_{\mathrm{x}}$ recycling rates. We incorporate recent advances in isoprene oxidation chemistry into the SAPRC-07 chemical mechanism within the US EPA (United States Environmental Protection Agency) CMAQ model. The results show improved model performance for a range of species compared against aircraft observations from the INTEX-NA/ICARTT 2004 field campaign. We further investigate the key processes in isoprene nitrate chemistry and evaluate the impact of uncertainties in the isoprene nitrate yield, $\mathrm{NO}_{\mathrm{x}}\left(\mathrm{NO}_{\mathrm{x}}=\mathrm{NO}+\mathrm{NO}_{2}\right)$ recycling efficiency, dry deposition velocity, and $\mathrm{RO}_{2}+\mathrm{HO}_{2}$ reaction rates. We focus our examination on the southeastern United States, which is impacted by both abundant isoprene emissions and high levels of anthropogenic pollutants. We find that $\mathrm{NO}_{\mathrm{x}}$ concentrations increase by $4-9 \%$ as a result of reduced removal by isoprene nitrate chemistry. $\mathrm{O}_{3}$ increases by 2 ppbv as a result of changes in $\mathrm{NO}_{\mathrm{x}}$. $\mathrm{OH}$ concentrations increase by $30 \%$, which can be primarily attributed to greater $\mathrm{HO}_{\mathrm{x}}$ production. We find that the model can capture observed total alkyl and multifunctional nitrates ( $\sum \mathrm{ANs}$ ) and their relationship with $\mathrm{O}_{3}$ by assuming either an isoprene nitrate
\end{abstract}

yield of $6 \%$ and daytime lifetime of 6 hours or a yield of $12 \%$ and lifetime of $4 \mathrm{~h}$. Uncertainties in the isoprene nitrates can impact ozone production by $10 \%$ and $\mathrm{OH}$ concentrations by $6 \%$. The uncertainties in $\mathrm{NO}_{\mathrm{x}}$ recycling efficiency appear to have larger effects than uncertainties in isoprene nitrate yield and dry deposition velocity. Further progress depends on improved understanding of isoprene oxidation pathways, the rate of $\mathrm{NO}_{\mathrm{x}}$ recycling from isoprene nitrates, and the fate of the secondary, tertiary, and further oxidation products of isoprene.

\section{Introduction}

Isoprene emissions are the dominant source of non-methane volatile organic compounds to the atmosphere (Guenther et al., 2006). Being highly reactive (lifetime $\sim 3 \mathrm{~h}$ at $\mathrm{OH}$ concentration of $1 \times 10^{6} \mathrm{~mol} \mathrm{~cm}^{-3}$ ), isoprene plays a central role in tropospheric chemistry. When isoprene reacts with $\mathrm{OH}$, six isomeric hydroperoxy radicals $\left(\mathrm{ISOPO}_{2}\right)$ are formed. When NO concentrations are greater than $\sim 150 \mathrm{ppt}$, $\mathrm{ISOPO}_{2}$ primarily reacts with $\mathrm{NO}$ to yield mainly alkoxy radicals and $\mathrm{NO}_{2}$. Subsequently, $\mathrm{O}_{3}$ is formed through $\mathrm{NO}_{2}$ photolysis, while $\mathrm{OH}$ and $\mathrm{NO}$ are regenerated in autocatalytic cycles. The minor channel forms hydroxynitrates (ISOPN, Table 1), which sequester $\mathrm{NO}_{\mathrm{x}}$ and therefore regulate $\mathrm{O}_{3}$ formation locally. There have been a number of laboratory studies reporting the ISOPN yield, with the value

Published by Copernicus Publications on behalf of the European Geosciences Union. 
ranging from $4.4 \%$ to $15 \%$ (Tuazon and Atkinson, 1990; Chen et al., 1998; Chuong and Stevens, 2002; Sprengnether et al., 2002; Patchen et al., 2007; Paulot et al., 2009a; Lockwood et al., 2010).

With the presence of a double bond, ISOPNs are highly reactive with respect to $\mathrm{OH}$ and $\mathrm{O}_{3}$ (Giacopelli et al., 2005; Paulot et al., 2009a; Lockwood et al., 2010). At OH concentration of $1 \times 10^{6} \mathrm{~mol} \mathrm{~cm}^{-3}$ and $40 \mathrm{ppbv} \mathrm{O}_{3}$, the lifetime of ISOPN with respect to $\mathrm{OH}$ is about $4 \mathrm{~h}$ (Paulot et al., 2009a) and to $\mathrm{O}_{3}$ is about $3 \mathrm{~h}$ (Lockwood et al., 2010), giving a combined lifetime slightly less than $2 \mathrm{~h}$. The products from ISOPN oxidation might either retain the nitrate functionality (Grossenbacher et al., 2001; Giacopelli et al., 2005; Perring et al., 2009a) or release $\mathrm{NO}_{\mathrm{x}}$ (Paulson and Seinfeld, 1992). Paulot et al. (2009a) estimate about $50 \%$ recycling efficiency of $\mathrm{NO}_{\mathrm{x}}(\alpha)$ from ISOPN $+\mathrm{OH} / \mathrm{NO}$ reactions and identified some of the organic nitrates produced by this reaction, including methyl vinyl ketone nitrate, methacrolein nitrate, and propanone nitrate. A recent field study confirmed the existence of these secondary organic nitrates compounds (Beaver et al., 2012). Some of these organic nitrates products, e.g., propanone nitrate, are found to be considerably longerlived than ISOPN and can serve as temporary reservoirs for $\mathrm{NO}_{\mathrm{x}}$, thereby impacting the $\mathrm{NO}_{\mathrm{y}}$ budget as well as $\mathrm{O}_{3}$ levels far from isoprene source region (Paulot et al., 2009a; 2012). The products and $\mathrm{NO}_{\mathrm{x}}$ recycling efficiency from ISOPN oxidation by $\mathrm{O}_{3}$ are poorly understood (Giacopelli et al., 2005; Lockwood et al., 2010).

Furthermore, there are also large uncertainties in isoprene $+\mathrm{NO}_{3}$ oxidation chemistry. Although only accounting for about 6-7\% of isoprene oxidation (Horowitz et al., 2007; $\mathrm{Ng}$ et al., 2008), studies suggest that isoprene can be an important sink for $\mathrm{NO}_{3}$ radical (Starn et al., 1998; Brown et al., 2009), and the reaction contributes substantially (30-60\%) to the formation of isoprene nitrates (ING) (von Kuhlmann et al., 2004; Horowitz et al., 2007; Paulot et al., 2012). The isoprene $+\mathrm{NO}_{3}$ reaction is initiated by $\mathrm{NO}_{3}$ addition to a double bond, followed by reaction with $\mathrm{O}_{2}$ to produce a nitroxy peroxy radical $\left(\mathrm{NISOPO}_{2}\right)$. Subsequent reaction of $\mathrm{NISOPO}_{2}$ with $\mathrm{NO}, \mathrm{NO}_{3}, \mathrm{RO}_{2}$, and $\mathrm{HO}_{2}$ can either result in functionalization, conserving the nitrate group, or release $\mathrm{NO}_{2}$ through dissociation. Large nitrates yields $(\sim 80 \%)$ have been reported in a number of experimental studies (Barnes et al., 1990; Berndt and Boge, 1997; Rollins et al., 2009; Perring et al., 2009b; Kwan et al., 2012), with the primary products identified as C5-nitrooxycarbonyl (NIT1), C5-nitrooxyhydroperoxide (NISOPOOH), and C5hydroxynitrate (ISOPN). Few studies have investigated the fate of these organic nitrates (Rollins et al., 2009); therefore, their oxidation products and $\mathrm{NO}_{\mathrm{x}}$ recycling efficiency are not well known.

In addition to photochemical loss, isoprene nitrates are also subject to removal by deposition. Measurements have found these multi-functional nitrates are soluble in water with large Henry's law constants (Shepson et al., 1996;
Treves et al., 2000). Their dry deposition velocities are less constrained, with measured values ranging from that of PAN $\left(0.4 \mathrm{~cm} \mathrm{~s}^{-1}\right.$, Shepson et al., 1996) to $\mathrm{HNO}_{3}\left(2.7 \mathrm{~cm} \mathrm{~s}^{-1}\right.$, Farmer and Cohen, 2008). Studies also disagree regarding the relative importance of removal by deposition (Horowitz et al., 2007) and removal by photooxidation (Shepson et al., 1996; Ito et al., 2007; Perring et al., 2009a).

Simulations of tropospheric ozone production are known to be highly sensitive to ISOPN yield (von Kuhlmann et al., 2004; Wu et al., 2007; Ito et al., 2007; Weaver et al., 2009; Paulot et al., 2012). For example, Wu et al. (2007) found a $10 \%$ reduction in global tropospheric ozone production while increasing the ISOPN yield from $4 \%$ to $12 \%$. Similar to the effects of ISOPN yield, recent work by Paulot et al. (2012) also highlighted the importance of $\mathrm{NO}_{\mathrm{x}}$ recycling efficiency as well as the representation of secondary nitrate photochemistry for the simulation of tropical ozone.

In additional to laboratory studies, field observations have been used to probe isoprene nitrate chemistry. For example, Horowitz et al. (2007) found that a $40 \%$ recycling efficiency together with a $4 \%$ ISOPN yield and a fast dry deposition rate best captured the alkyl and multifunctional nitrates measurements collected during the INTEX-NA/ICARTT (Intercontinental Chemical Transport Experiment-North America/International Consortium for Atmospheric Research on Transport and Transformation) field study during summer 2004 (Singh et al., 2006; Fehsenfeld et al., 2006). Using the same datasets, Perring et al. (2009a) inferred a $\mathrm{NO}_{\mathrm{x}}$ recycling efficiency between $3 \%$ and $33 \%$ depending on the assumed ISOPN yields $(4-12 \%)$.

Recently, there have also been many studies devoted to isoprene oxidation under low $\mathrm{NO}_{\mathrm{x}}$ conditions (Lelieveld et al., 2008; Paulot et al., 2009b; Peeters et al., 2009; Peeters and Müller, 2010; Crounse et al., 2011). These studies address some of the important challenges with isoprene chemistry including (i) the apparent discrepancy between observed and modeled $\mathrm{HO}_{\mathrm{x}}$ abundance under isoprene rich conditions (Thornton et al., 2002; Ren et al., 2008; Butler et al., 2008; Lelieveld et al., 2008); and (ii) the link between isoprene gas phase oxidation and the formation of organic aerosols (Claeys et al., 2004; Edney et al., 2005; Kleindienst et al., 2007; Paulot et al., 2009b; Surratt et al., 2010).

The tropical forest has been a focus area for many recent studies (Lelieveld et al., 2008; Butler et al., 2008; Karl et al., 2009; Stone et al., 2011; Whalley et al., 2011) that aim to improve the understanding of isoprene oxidation chemistry. These locations are mostly characterized by very large biogenic emissions with pristine conditions, where isoprene peroxy radicals are dominated by reactions with $\mathrm{HO}_{2}$ and isomerization. Nevertheless, anthropogenic emissions are known to substantially affect the relative importance of isoprene oxidation pathways and products (e.g., alkyl and multifunctional nitrates, epoxides). The southeastern United States is a region known for its abundant isoprene emissions and anthropogenic pollutants, providing a good opportunity 
Table 1. Speciated alkyl and multifunctional nitrates in the IS scheme.

\begin{tabular}{|c|c|c|c|}
\hline Group & & Species & Description \\
\hline \multirow[t]{3}{*}{$\begin{array}{l}\text { isoprene nitrates } \\
\text { (ING) }\end{array}$} & $\mathrm{ING}_{0}$ & $\begin{array}{l}\text { ISOPND } \\
\text { ISOPNB } \\
\text { NIT1 } \\
\text { NISOPOOH }\end{array}$ & $\begin{array}{l}\delta \text {-hydroxy isoprene nitrate } \\
\beta \text {-hydroxy isoprene nitrate } \\
\text { C5-nitrooxycarbonyl } \\
\text { C5-nitrooxyhydroperoxide }\end{array}$ \\
\hline & $\mathrm{ING}_{1}$ & $\begin{array}{l}\text { MVKN } \\
\text { MACRN } \\
\text { ETHLN } \\
\text { RNO3I }\end{array}$ & $\begin{array}{l}\text { methylvinylketone nitrate } \\
\text { methacrolein nitrate } \\
\text { ethanal nitrate } \\
\text { lumped organic nitrates from isoprene }\end{array}$ \\
\hline & $\mathrm{ING}_{2}$ & $\begin{array}{l}\text { PROPNN } \\
\text { PROPNNB }\end{array}$ & $\begin{array}{l}\text { propanone nitrate formed from } \\
\text { isoprene }+\mathrm{OH} \\
\text { propanone nitrate formed from } \\
\text { isoprene }+\mathrm{NO}_{3}\end{array}$ \\
\hline $\begin{array}{l}\text { other alkyl and } \\
\text { multifunctional } \\
\text { nitrates }\end{array}$ & & RNO3 & $\begin{array}{l}\text { lumped organic nitrates from sources } \\
\text { other than isoprene }\end{array}$ \\
\hline
\end{tabular}

to understand the impact of isoprene nitrates in a region influenced by both biogenic emissions and a range of $\mathrm{NO}_{\mathrm{x}}$ concentrations.

In this study, we incorporate recent advances in isoprene oxidation chemistry into the SAPRC-07 chemical mechanism (Carter, 2010a) within the US EPA Community Multiscale Air Quality (CMAQ) model (Byun and Schere, 2006). Data from the INTEX-NA/ICARTT campaign during the summer of 2004 (Singh et al., 2006; Fehsenfeld et al., 2006) are used to evaluate model performance and constrain the uncertainties in the isoprene nitrate chemistry. The observations include measurements of speciated $\mathrm{NO}_{\mathrm{y}}$, organic compounds, and aerosols, comprising a comprehensive dataset for characterizing the summer continental boundary layer of the eastern United States. In contrast to previous modeling studies, we use a highly detailed representation of isoprene chemistry and examine the effect on areas where both biogenic and anthropogenic emissions are important. In Sect. 2, we describe the modeling system and the updated isoprene oxidation scheme. In Sect. 3.1, we evaluate the CMAQ model results with INTEX-NA/ICARTT observations. We further investigate the sources and sinks of the isoprene peroxy radicals and isoprene nitrates (Sects. 3.2 and 3.3). We then examine the sensitivity of model results to the most important uncertainties in our current understanding of isoprene nitrate chemistry (Sect. 3.4), with an emphasis on $\mathrm{O}_{3}$ and $\mathrm{OH}$ concentrations (Sect. 3.5).

\section{Methods and data}

We start this section by describing the updates to isoprene oxidation chemistry, followed by discussion of the photochem- ical modeling system and the observational datasets used to constrain the model results.

\subsection{Updated isoprene oxidation scheme}

We base our core chemistry on a modified version of SAPRC-07, including changes for air toxics (i.e., SAPRC07T (Hutzell et al., 2012), referred to as the BASE scheme). A new version of the mechanism is developed in this study (referred to as the standard isoprene scheme (IS)), which incorporates recent advances in isoprene oxidation chemistry (Paulot et al., 2009a, b; Lockwood et al., 2010; Peeters and Müller, 2010; Crounse et al., 2011; Rollins et al., 2009). The changes include a more explicit representation of isoprene nitrate formation from $\mathrm{OH} / \mathrm{NO}$ and $\mathrm{NO}_{3}$ pathways as well as modification to the isoprene chemistry under low- $\mathrm{NO}_{\mathrm{x}}$ conditions. The updated chemistry is summarized in Fig. 1; see Tables S1 and S2 (Supplement) for a complete listing of the compounds and reactions. Each of the speciated isoprene nitrates is described in Table 1.

In the standard SAPRC-07 mechanism (Carter, 2010a, b), isoprene nitrates are represented, along with all other nonPAN analogue organic nitrates, as a lumped organic nitrate species $\left(\mathrm{RNO}_{3}\right)$, with $k_{\mathrm{OH}}$ of $7.2 \times 10^{-12} \mathrm{~cm}^{3} \mathrm{~mol}^{-1} \mathrm{~s}^{-1}$ and $\mathrm{NO}_{\mathrm{x}}$ recycling efficiency of about $30 \%$. In the $\mathrm{OH} / \mathrm{NO}$ reactions of isoprene, the $\mathrm{RNO}_{3}$ yield is $9.3 \%$. This $\mathrm{RNO}_{3}$ yield is a derived value. It is treated as a parameter and adjusted to improve the comparison of SAPRC-07 simulated $\mathrm{O}_{3}$ measurements from laboratory chamber experiments. The $\mathrm{O}_{3}$ comparison is very sensitive to the $\mathrm{RNO}_{3}$ yield parameter. In the $\mathrm{NO}_{3}$ oxidation pathway, a large fraction $(75 \%)$ of organic nitrates is assumed to be long-lived and is treated as lost nitrogen $(\mathrm{XN})$, and the $\mathrm{RNO}_{3}$ yield is only $6.4 \%$. 


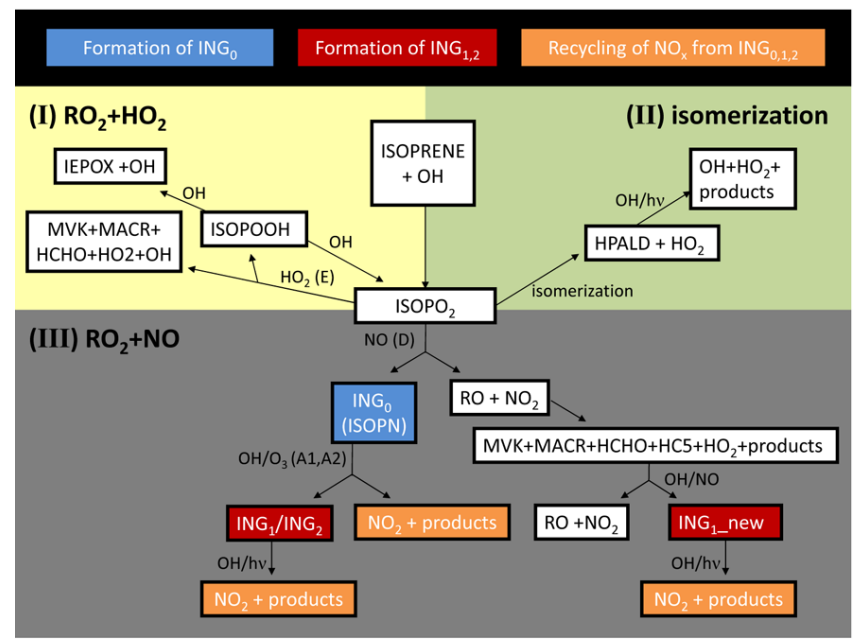

Fig. 1a. Updated oxidation scheme for isoprene $+\mathrm{OH}$, noting the formation of first generation isoprene nitrates $\left(\mathrm{ING}_{0}\right)$, later generation isoprene nitrates $\left(\mathrm{ING}_{1,2}\right)$, and recycling of $\mathrm{NO}_{\mathrm{x}}$ from isoprene nitrates. Reactions modified by the sensitivity studies in Sect. 3.4 are denoted by the letters in parentheses (A-E).

The IS mechanism treats isoprene nitrates explicitly. Isoprene oxidation reactions from $\mathrm{OH}$ are shown in Fig. 1a. In the presence of NO, isoprene nitrates can form as described by Pathway III in Fig. 1a. The formation and the subsequent oxidation of organic nitrates are largely based on the work of Paulot et al. (2009a). The $\delta$ - and $\beta$-hydroxy isoprene nitrates (ISOPN) are represented separately, as their fate varies substantially from each other (Paulot et al., 2009a). Formation and photooxidation of organic nitrates from MVK and MACR, i.e., methyl vinyl ketone nitrate (MVKN) and methacrolein nitrate (MACRN), are also treated following Paulot et al. (2009a). ISOPN reacts rapidly with $\mathrm{OH}$ (weighted average $k_{\mathrm{OH}}=6.2 \times 10^{-11} \mathrm{~cm}^{3} \mathrm{~mol}^{-1} \mathrm{~s}^{-1}$ for $\delta$ and $\beta$-branch), releasing about $60 \%$ of $\mathrm{NO}_{\mathrm{x}}$, with the rest forming methyl vinyl ketone nitrate (MVKN), methacrolein nitrate (MACRN), propanone nitrate (PROPNN), and ethanal nitrate (ETHLN). PROPNN reaction with OH (Zhu et al., 1991; Paulot et al., 2012) and photolysis (Roberts and Fajer, 1989; Barnes et al., 1993; Saunders et al., 2003) are added, and PROPNN is substantially longer-lived $\left(k_{\mathrm{OH}}=\right.$ $4.0 \times 10^{-13} \mathrm{~cm}^{3} \mathrm{~mol}^{-1} \mathrm{~s}^{-1}$ ) than other second-generation isoprene nitrates. Photolysis rates of MVKN and ETHLN are assumed to be the same as that of PROPNN. For ISOPN $+\mathrm{O}_{3}$ reactions, we use the reaction rate coefficients (weighted average $k_{\mathrm{O}_{3}}=8.4 \times 10^{-17} \mathrm{~cm}^{3} \mathrm{~mol}^{-1} \mathrm{~s}^{-1}$ ) from Lockwood et al. (2010). As little is known about the products and $\mathrm{NO}_{\mathrm{x}}$ recycling efficiency from this pathway, we estimate the likely products largely based on the SAPRC mechanism generation system (Carter, 2000, 2010b). We assume a lower $\mathrm{NO}_{\mathrm{x}}$ recycling $(30 \%)$ from ISOPN $+\mathrm{O}_{3}$ than from ISOPN $+\mathrm{OH} / \mathrm{NO}$ reactions. In addition to the species listed above, a general isoprene nitrate species $\left(\mathrm{RNO}_{3} \mathrm{I}\right)$ is added to

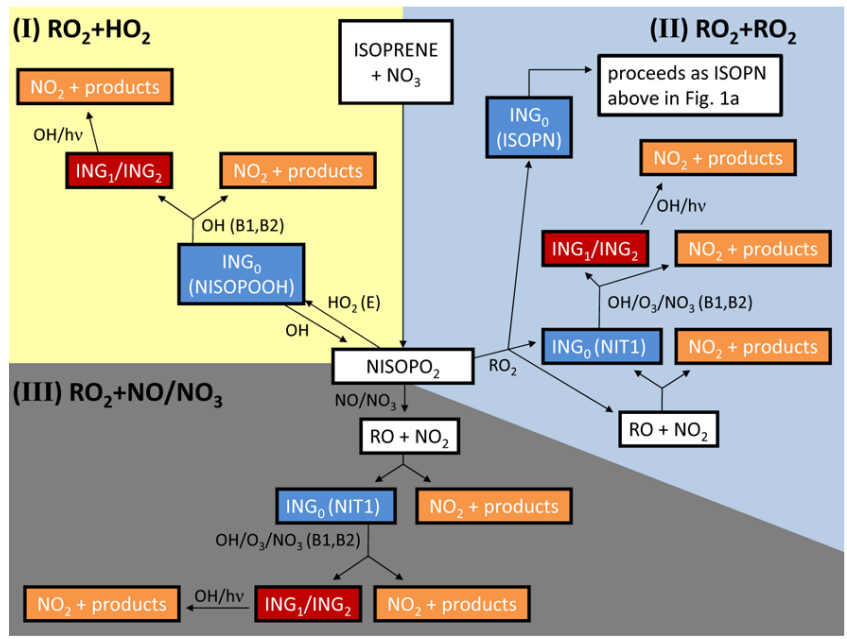

Fig. 1b. Updated oxidation scheme for isoprene $+\mathrm{NO}_{3}$. The colors retain the same meaning as in Fig. 1a.

represent additional second-generation organic nitrates formation. $\mathrm{RNO}_{3} \mathrm{I}$ is assumed to react readily with $\mathrm{OH}\left(k_{\mathrm{OH}}=\right.$ $8 \times 10^{-12} \mathrm{~cm}^{3} \mathrm{~mol}^{-1} \mathrm{~s}^{-1}$ ).

The oxidation of isoprene by $\mathrm{NO}_{3}$ (Fig. 1b) is also updated in the IS mechanism. A nitrooxy-carbonyl (NIT1) yield of $70 \%$ is used in the $\mathrm{RO}_{2}+\mathrm{NO} / \mathrm{NO}_{3}$ reactions (Rollins et al., 2009) (Pathway III in Fig. 1b). The $\mathrm{RO}_{2}+\mathrm{HO}_{2}$ reaction (Pathway I in Fig. 1b) yields a nitrooxy-hydroperoxide (NISOPOOH). For $\mathrm{RO}_{2}+\mathrm{RO}_{2}$ reactions (Pathway II in Fig. 1b), a branching ratio of $50 \%$ is assumed for the radical propagating pathway versus carbonyl (NIT1) and alcohol (ISOPN) formation reactions. The subsequent oxidation of NIT1 by $\mathrm{NO}_{3}$ largely follows Rollins et al. (2009), using a reaction rate coefficient of $7.0 \times 10^{-14} \mathrm{~cm}^{3} \mathrm{~mol}^{-1} \mathrm{~s}^{-1}$, which is about an order of magnitude slower than that of isoprene $+\mathrm{NO}_{3}$ reactions. Reaction of NIT1 with $\mathrm{O}_{3}$ is also included, and the reaction rate coefficient $\left(2.5 \times 10^{-17} \mathrm{~cm}^{3} \mathrm{~mol}^{-1} \mathrm{~s}^{-1}\right)$ is estimated by scaling the NIT1 $+\mathrm{NO}_{3}$ reaction rate coefficient using methacrolein as a reference compound. Products from $\mathrm{NIT} 1+\mathrm{O}_{3}$ reactions and the $\mathrm{NIT} 1+\mathrm{OH}$ oxidation scheme are estimated, largely based on the SAPRC mechanism generation system. The IS mechanism assumes $70 \% \mathrm{NO}_{\mathrm{x}}$ recycling efficiency from NIT1 $+\mathrm{O}_{3}$ oxidation. NIT1 is estimated to react rapidly with $\mathrm{OH}\left(k_{\mathrm{OH}}=\right.$ $3.0 \times 10^{-11} \mathrm{~cm}^{3} \mathrm{~mol}^{-1} \mathrm{~s}^{-1}$ ), with the reaction having a large yield of propanone nitrate (PROPNNB) and releasing little $\mathrm{NO}_{\mathrm{x}}$. NISOPOOH is treated following Paulot et al. (2012), which assumes its fate is similar to that of hydroxyhydroperoxide formed from isoprene $+\mathrm{OH}$ reactions.

While the chemistry simulation maintains the specificity described above, our discussion of the results groups isoprene nitrates as first-generation products $\left(\mathrm{ING}_{0}\right.$, including $\delta$ - and $\beta$-hydroxynitrates, C5-nitrooxycarbonyl, and C5-nitrooxyhydroperoxide) and secondary isoprene nitrates (ING 1 and $\mathrm{ING}_{2}$ ), as in Paulot et al. (2012). $\mathrm{ING}_{1}$ represents 
short-lived species, including methyl vinyl ketone nitrate, methacrolein nitrate, ethanal nitrate, and a general isoprene nitrate species $\left(\mathrm{RNO}_{3} \mathrm{I}\right) . \mathrm{ING}_{2}$ represents propanone nitrate, as it is substantially longer-lived. We use Henry's law constants of $\mathrm{H}_{298}=1.7 \times 10^{4} \mathrm{M} \mathrm{atm}^{-1}$ for $\mathrm{ING}_{0}$ and $\mathrm{ING}_{1}$ (von Kuhlmann et al., 2003; Ito et al., 2007) and $\mathrm{H}_{298}=10^{3} \mathrm{M} \mathrm{atm}^{-1}$ for $\mathrm{ING}_{2}$ (Sander, 1999).

In addition to the changes in isoprene nitrate chemistry, isoprene oxidation chemistry under low- $\mathrm{NO}_{\mathrm{x}}$ conditions is updated. In the standard SAPRC-07 mechanism, the low$\mathrm{NO}_{\mathrm{x}}$ oxidation of isoprene is represented by the formation of lumped organic hydroperoxides $(\mathrm{R} 6 \mathrm{OOH})$ from the $\mathrm{RO}_{2}+\mathrm{HO}_{2}$ pathway.

Here we represent isoprene hydroperoxides explicitly, with updated chemistry including epoxides formation and recycling of $\mathrm{OH}$ (Paulot et al., 2009b) (Pathway I in Fig. 1a). Formation of MVK/MACR (12\%) under low- $\mathrm{NO}_{\mathrm{x}}$ conditions is attributed to a radical channel in the $\mathrm{ISOPO}_{2}+\mathrm{HO}_{2}$ reaction (Paulot et al., 2009b). We also incorporate isoprene peroxy radical isomerization reactions and subsequent $\mathrm{OH}-$ reformation from hydroperoxy-aldehydes (HPALD) (Peeters et al., 2009; Peeters and Müller, 2010) (Pathway II in Fig. 1a). The measured isomerization rate from Crounse et al. (2011) is used, which is $\sim 50$ times slower than that predicted from theoretical calculations (Peeters et al., 2009; Peeters and Müller, 2010).

Additional changes in the mechanism include revised reaction rates for $\mathrm{RO}_{2}+\mathrm{HO}_{2}$. The reaction rate coefficient in the base SAPRC-07 mechanism is independent of the size of the peroxy radical:

$k=3.80 \times 10^{-13} \exp (900 / \mathrm{T})$.

In fact, $k$ increases with the size of the peroxy radical (Rowley et al., 1992; Jenkin and Hayman, 1995; Boyd et al., 2003), and we use the expression derived by Saunders et al. (2003):

$k=2.91 \times 10^{-13} \exp (1300 / \mathrm{T})[1-\exp (-0.245 n)]$

where $n$ is the number of atoms of carbon in the peroxy radical. For isoprene peroxy radicals, this increases the reaction rate by a factor of 2 at $298 \mathrm{~K}$.

\subsection{CMAQ model}

CMAQ model version 4.7 is used for photochemical air quality modeling. The inputs to CMAQ are the anthropogenic emissions and meteorological conditions; outputs are concentrations and deposition fluxes for each hour of the simulation. CMAQ employs an Eulerian grid structure to explicitly simulate biogenic emissions, gas-phase, aqueous, and mixedphase chemistry, advection and dispersion, aerosol thermodynamics and physics, and wet and dry deposition. A more complete description and evaluation of the CMAQ processes and inputs are available in Foley et al. (2010), Carlton et al. (2010), and Appel et al. (2011). CMAQ with the base SAPRC-07T mechanism has been shown to reliably simulate atmospheric concentrations of ozone and aerosols (Hutzell et al., 2012).

The spatial domain covers the entire continental US and a portion of Canada and Mexico. The model includes 24 vertical layers at $36 \mathrm{~km}$ horizontal resolution. Chemical boundary conditions are based on the default vertical profiles of gaseous species and aerosols in CMAQ that represent clean air conditions. The model simulation period is 00:00 UTC 1 July to 00:00 UTC 16 August 2004, with the first 96 hours discarded as spin-up to remove the impact of initial conditions.

We use 3-D meteorology fields developed by the 5th Mesoscale Meteorological model (MM5; Grell et al., 1994) version 3.7.4 to drive the photochemical model. The area, onroad mobile, non-road mobile, and point emissions are processed using the Sparse Matrix Operator Kernel Emissions (SMOKE, Houyoux et al., 2000) based on US EPA 2002 National Emission Inventory (NEI) version 3 (http: //www.epa.gov/ttn/chief/net/2002inventory.html). Year specific updates for 2004 are included for major power plants and vehicle emissions. We adjust all $\mathrm{NO}_{\mathrm{x}}$ emissions (reduce by $20 \%$ ), as Napelenok et al. (2008) suggests reduced $\mathrm{NO}_{\mathrm{x}}$ emissions are in better agreement with satellite $\mathrm{NO}_{2}$ measurements for the southeastern United States. For biogenic emissions, studies have found isoprene emissions estimated by the two widely used models, i.e., the Model of Emissions of Gases and Aerosols from Nature (MEGAN) and the Biogenic Emission Inventory System (BEIS), differ by about a factor of 2 (Warneke et al., 2010; Carlton and Baker, 2011). Model predictions compared with measurements during a July 1998 intensive field campaign in the Ozarks find that MEGAN tends to overpredict isoprene emissions, while BEIS shows underpredictions (Carlton and Baker, 2011). To account for the potential underestimation from BEIS, we increase the isoprene emissions calculated by BEIS version 3 (BEIS3) by $50 \%$.

The treatment of biogenic secondary organic aerosol (SOA) formation follows that in CMAQv4.7 (Carlton et al., 2010). Biogenic SOA formation from gas-phase oxidation of isoprene, monoterpenes, and sesquiterpenes is represented. Isoprene $\mathrm{SOA}$ is formed exclusively by $\mathrm{OH}$ oxidation. The yield from isoprene semivolatile products and their partitioning parameters are based on the low- $\mathrm{NO}_{\mathrm{x}}$ experimental results of Kroll et al. (2006). Monoterpene and sesquiterpene SOA is formed by $\mathrm{OH}, \mathrm{NO}_{3}$, and $\mathrm{O}_{3}$ oxidation, with the partitioning parameters based on the experimental data of Griffin et al. (1999). Nonvolatile SOA formation including acid enhanced isoprene SOA (Surratt et al., 2007) is also accounted for in the model. 


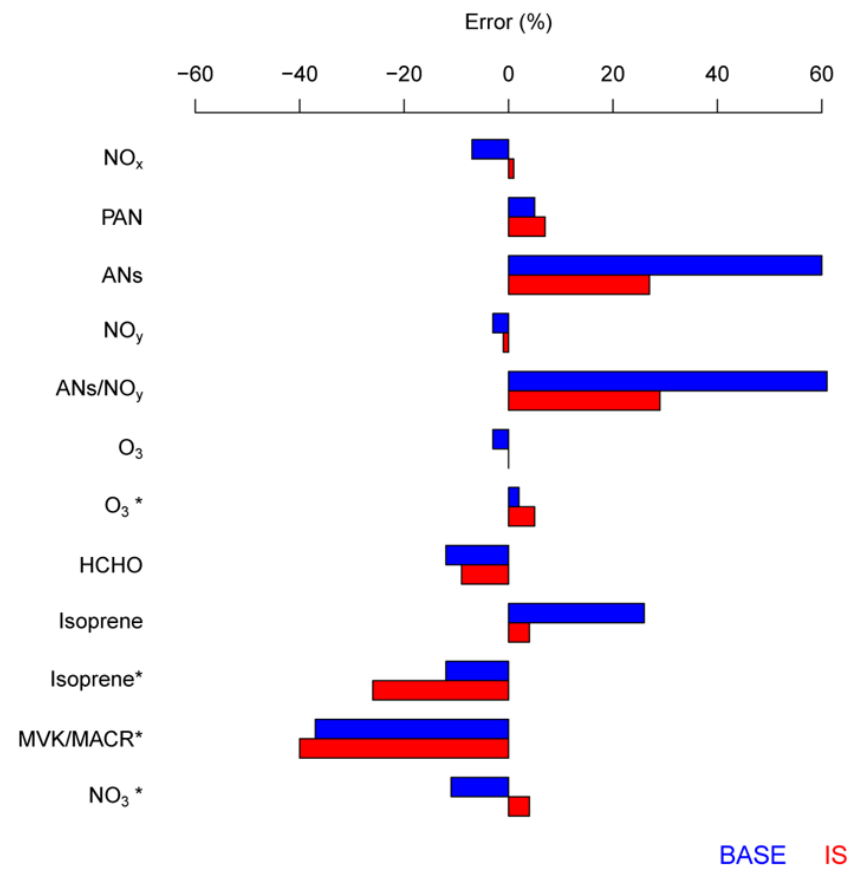

Fig. 2. Evaluation of CMAQ using observations between the surface and $2 \mathrm{~km}$ (10-18 LST, except $\mathrm{NO}_{3}$ is $\left.21-04 \mathrm{LST}\right) .{ }^{*}$ indicates data from WP-3D. HCHO is based on the average of the University of Rhode Island and NCAR measurements due to the systematic difference $(\sim 35 \%)$ between the two datasets. The CMAQ model results are sampled at the GPS location of the 1 min measurements. Error is reported the median of the quantity CMAQ minus observations, divided by the median of the observations.

\subsection{Observational datasets}

We use data from the INTEX-NA/ICARTT campaigns in the summer of 2004 (1 July to 15 August) (Singh et al., 2006; Fehsenfeld et al., 2006) to evaluate model performance and constrain the uncertainties in the isoprene nitrate chemistry. Observations are available from NASA DC- 8 and NOAA WP-3D (18 flights on each aircraft). The two aircrafts have different sampling emphasis, with DC-8 targeted at regional airmasses over North America and WP-3D aimed at local flows downwind of urban centers and point sources in the northeastern United States (Fig. 3). During INTEXNA/ICARTT, the total alkyl and multifunctional nitrates ( $\sum$ ANs) are measured by thermal dissociation laser induced fluorescence (TD-LIF, Day et al., 2002). The dataset represents the most spatially extensive measurements of $\sum$ ANs over the eastern United States to date. While $\sum$ ANs includes isoprene nitrates (ING), the $\sum$ ANs measurement also includes other organic nitrates as well. As mentioned, these same data have been used in previous studies investigating the formation and fate of isoprene nitrates (Horowitz et al., 2007; Perring et al., 2009a).
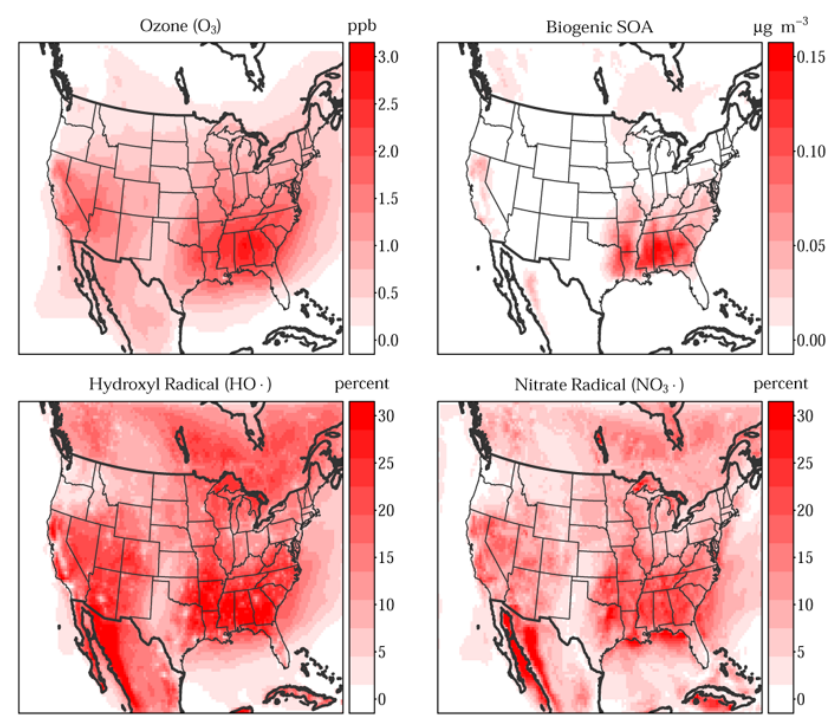

Oxides of Nitrogen $\left(\mathrm{NO}^{2}\right)$
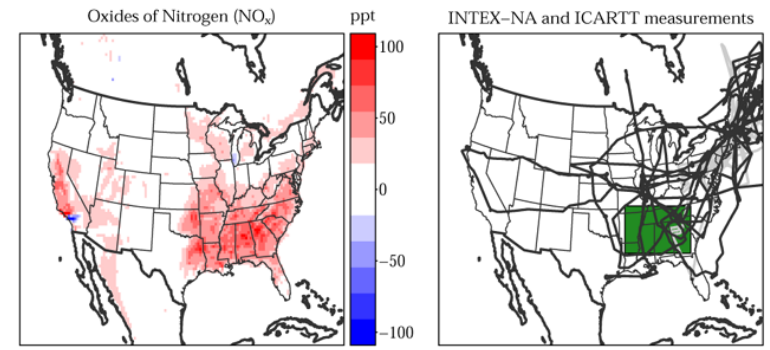

Fig. 3. Changes in the surface concentrations of selected model species between the base and IS simulations averaged over the entire modeling period. DC- 8 and WP-3D flight tracks are shown in dark grey and light grey, respectively. The green box indicates the southeastern United States subdomain described in the Results section.

\section{Results}

\subsection{Evaluation of IS mechanism with INTEX-NA/ICARTT observations}

With the updated isoprene nitrate chemistry, the IS simulation shows improved performance over a range of species measured by aircraft during the INTEX-NA/ICARTT 2004 field study. Model performance of selected species within the boundary layer is summarized in Fig. 2.

Isoprene nitrates (ING) and $\sum$ ANs are substantially shorter-lived in the IS scheme (Table 2). As a result, $\sum$ ANs concentrations decrease by $20 \%$, reducing the bias from $60 \%$ to $30 \% . \mathrm{NO}_{\mathrm{x}}$ concentrations are slightly underestimated in the base case $(-7 \%)$, and have little bias $(1 \%)$ in the IS case. The increase in $\mathrm{NO}_{\mathrm{x}}$ is due to shorter photochemical lifetime of isoprene nitrates and reduced net removal of $\mathrm{NO}_{\mathrm{x}}$ by isoprene nitrate chemistry. $\mathrm{HNO}_{3}$ (not shown) is biased low in both cases $(-44 \%$ for the base, $-33 \%$ for IS scheme). For PAN and $\mathrm{NO}_{\mathrm{y}}\left(\mathrm{NO}_{\mathrm{y}}=\mathrm{NO}_{\mathrm{x}}+\right.$ $\sum \mathrm{PNs}+\sum \mathrm{ANs}+\mathrm{HNO}_{3}+$ minor species), both model runs 
Table 2. $\mathrm{NO}_{\mathrm{X}}$ recycling efficiency and isoprene nitrates lifetime from the base case, IS scheme, and its sensitivity simulations. The isoprene nitrates (ING) are a subset of the alkyl and multifunctional nitrates (ANs).

\begin{tabular}{|c|c|c|c|c|c|c|}
\hline \multirow[t]{2}{*}{ Name } & \multirow[t]{2}{*}{ Description } & \multirow[t]{2}{*}{$\begin{array}{r}\mathrm{ING}_{0} \text { recycling of } \\
\mathrm{NO}_{\mathrm{x}}(\alpha)\end{array}$} & \multicolumn{2}{|c|}{$\begin{array}{c}\text { Daytime } \\
\text { lifetime (h) }\end{array}$} & \multicolumn{2}{|c|}{$\begin{array}{l}\text { Nighttime } \\
\text { lifetime (h) }\end{array}$} \\
\hline & & & $\sum \mathrm{ANs}$ & ING & $\sum \mathrm{ANs}$ & ING \\
\hline base & base & $29 \%$ & 13 & & 121 & \\
\hline IS & IS & $29 \%$ & 7.7 & 6.1 & 44 & 31 \\
\hline A1 & day $100 \% \mathrm{NO}_{\mathrm{x}}$ & $71 \%$ & 5.9 & 3.5 & 30 & 16 \\
\hline $\mathrm{A} 2$ & day $100 \%$ ING & $8 \%$ & 10 & 9.7 & 58 & 48 \\
\hline B1 & night $100 \% \mathrm{NO}_{\mathrm{x}}$ & $57 \%$ & 6.4 & 4.3 & 35 & 23 \\
\hline $\mathrm{B} 2$ & night $100 \%$ ING & $21 \%$ & 8.5 & 7.3 & 72 & 62 \\
\hline $\mathrm{C}$ & fast deposition & $29 \%$ & 6.4 & 4.2 & 40 & 26 \\
\hline $\mathrm{D}$ & low ING yield & $28 \%$ & 8.1 & 6.3 & 43 & 29 \\
\hline $\mathrm{E}$ & slow $\mathrm{HO}_{2}+\mathrm{RO}_{2}$ & $33 \%$ & 7.4 & 5.9 & 41 & 30 \\
\hline
\end{tabular}

show good agreement with observations (bias within $7 \%$ for PAN, and within $-3 \%$ for $\mathrm{NO}_{\mathrm{y}}$ ). Observations suggest $\sum$ ANs are important components of $\mathrm{NO}_{\mathrm{y}}(13 \%)$. The base case substantially overestimates the $\sum \mathrm{ANs}: \mathrm{NO}_{\mathrm{y}}$ ratio, whereas the IS simulation reduces the bias by about a factor of 2. Corresponding to the increase in $\mathrm{NO}_{\mathrm{x}}$ concentrations, $\mathrm{O}_{3}$ levels increase slightly (1-2 ppbv) in the IS simulation and both model runs agree well with observed concentrations (bias within $\pm 5 \%$ ).

Isoprene concentrations from the DC-8 measurements are slightly overestimated by the base case (bias of $26 \%$ ), whereas the IS case shows very little bias (4\%). For measurements from the WP-3D, slight underestimations are found in both runs $(-12 \%$ from the base, $-26 \%$ from IS). The decreases in isoprene concentrations in the IS case can be related to the increase in $\mathrm{OH}(\sim 30 \%$, as shown below). Oxidation products from isoprene, methyl-vinyl ketone (MVK) and methacrolein (MACR) are also measured by the WP-3D flights. Modeled MVK and MACR are well correlated with observations $\left(R^{2}=0.66\right)$, however both simulations underpredict the concentrations of these species by $40 \%$. Underestimation of MVK and MACR could be partly attributed to the bias in isoprene, while errors in modeled $\mathrm{OH}$ concentrations might cause additional underpredictions of these isoprene oxidation products. Formaldehyde (HCHO) increases slightly $(4 \%)$ in the IS case, and both simulations show some underpredictions (bias from base case $=-12 \%$, and bias from IS $=-9 \%$ ).

For radical species, $\mathrm{NO}_{3}$ increases by $35 \%$ as a result of increased $\mathrm{NO}_{\mathrm{x}}$ and $\mathrm{O}_{3}$, and the simulation shows good agreement with observations (bias of $4 \%$ ). Concentrations of $\mathrm{OH}$ increase by $30 \%$, with the bias improved from $-30 \%$ in the base simulation to about $-20 \%$ in the IS case. Performance of $\mathrm{HO}_{2}$ also improves slightly with bias reduced from about $-30 \%$ to $-25 \%$. A recent study suggests the traditional $\mathrm{OH}$ measurements made by laser-induced fluorescence (LIF) using the Penn State Ground-based Tropospheric Hydrogen
Oxides Sensor (used in 2004 INTEX-NA/ICARTT study) tend to overestimate the concentrations due to internally generated $\mathrm{OH}$, likely from oxidation from biogenic VOCs (Mao et al., 2012). It is also reported that $\mathrm{HO}_{2}$ measured by LIF is likely subject to interference by $\mathrm{RO}_{2}$ from isoprene, alkenes, or aromatics (Fuchs et al. 2011). Therefore, caution should be taken when interpreting $\mathrm{OH}$ and $\mathrm{HO}_{2}$ performance, especially when biogenic VOCs are abundant. We find the increase in CMAQ simulated $\mathrm{HO}_{\mathrm{x}}$ is partly driven by their increased production. The change is related to a number of sources: rapid photolysis of HPALD, increased photolysis from the increase of $\mathrm{O}_{3}$, and increased photolysis from the increased abundance of isoprene oxidation products (e.g., glyoxal and methylglyoxal). Meanwhile, the changes in $\mathrm{NO}_{\mathrm{x}}$ due to updates in isoprene nitrate chemistry further increase $\mathrm{OH}$ concentrations by shifting the partitioning between $\mathrm{HO}_{2}$ and $\mathrm{OH}$ through $\mathrm{HO}_{2}+\mathrm{NO}$ reaction.

Above the planetary boundary layer in the free troposphere, the impact of the more detailed isoprene chemistry is smaller (Fig. S1). Furthermore, the model underestimates ozone and $\mathrm{NO}_{\mathrm{y}}$ in the free troposphere, potentially due to errors in vertical mixing or boundary conditions. Because of these biases and because the short lifetime of isoprene means that relatively little is transported to the free troposphere, we restrict our analysis to concentrations within the planetary boundary layer, where the impact of these biases are reduced.

Changes in modeled surface concentrations of selected species from the IS simulation compared to the base case are shown in Fig. 3. $\mathrm{NO}_{\mathrm{x}}$ concentrations increase over extended regions of the continent, with a maximum increase of 4080 pptv ( $4 \%$ ) over the southeastern US and California where there are abundant isoprene emissions. In contrast to the increase of $\mathrm{NO}_{\mathrm{x}}$ in isoprene rich regions, decreases are found in urban areas with very high $\mathrm{NO}_{\mathrm{x}}$ but relatively low isoprene concentrations (e.g., Los Angeles). In these urban locations, $\mathrm{OH}$ concentrations increase as a result of increased $\mathrm{O}_{3}$ levels, 


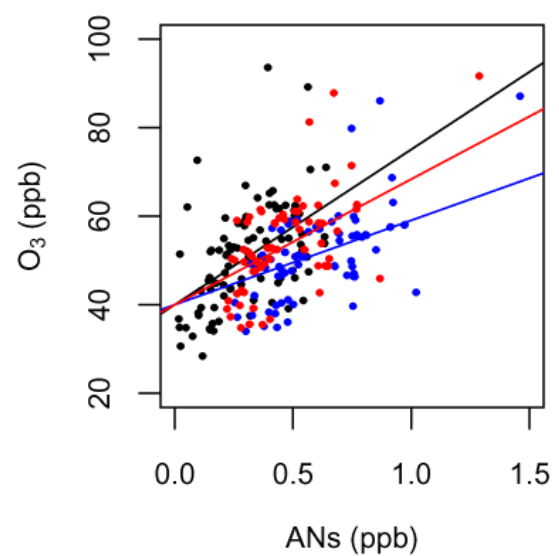

Fig. 4. Observed and simulated relationship between $\mathrm{O}_{3}$ and EANs. Black circles are the daytime observations (11-19LST) within $2 \mathrm{~km}$ of the surface and with isoprene concentration greater than 500 pptv. The blue and red circles are values from the base and IS simulations, respectively, sampled at the location and time of measurements. The black line is the best fit of observations (slope $=35.1$, intercept $=40.0, R^{2}=0.24, p$ value $=$ $\left.4.05 \times 10^{-7}\right)$. The blue line is the best fit for the base simulation (slope $=19.1$, intercept fixed at 40.0, squared correlation coefficient of $0.33, p$ value: $<2.2 \times 10^{-16}$ ), and the red line is the best fit for the IS simulation (slope $=28.4$, intercept fixed at 40.0 , squared correlation coefficient of $0.33, p$ value: $<2.2 \times 10^{-16}$ ).

causing more rapid formation of $\mathrm{HNO}_{3}$ and therefore a decrease in $\mathrm{NO}_{\mathrm{x}}$.

Corresponding to the increase in $\mathrm{NO}_{\mathrm{x}}$ concentrations, $\mathrm{O}_{3}$ levels increase by up to $3 \mathrm{ppbv}$ with the spatial pattern correlated well with the changes in $\mathrm{NO}_{\mathrm{x}}$. Concentrations of $\mathrm{OH}$, $\mathrm{HO}_{2}$ (not shown), and $\mathrm{NO}_{3}$ radical also increase by $\sim 30 \%$, $\sim 6 \%$, and $\sim 20 \%$ respectively at these locations. With the increases in oxidants levels $\left(\mathrm{OH}, \mathrm{O}_{3}, \mathrm{NO}_{3}\right)$, biogenic SOA is increased by $\sim 0.1 \mu \mathrm{g} / \mathrm{m}^{3}$ (i.e., $10-20 \%$ ) in the southeastern United States. We find greater changes when averaging within the boundary layer $(<2 \mathrm{~km})$ for the southeastern US: $\mathrm{NO}_{\mathrm{x}}, 9 \% ; \mathrm{HO}_{2}, 11 \%$; and $\mathrm{NO}_{3}, 67 \%$.

We further evaluate model performance using the correlation of $\mathrm{O}_{3}$ versus $\sum$ ANs (Fig. 4) as measured during INTEX-NA/ICARTT. Both are produced from $\mathrm{RO}_{2}$ reactions with NO, and therefore might provide useful information regarding the $\sum$ ANs formation and fate. We restrict our analysis to samples with high isoprene concentrations (> 500 pptv) to focus on isoprene rich air masses. Using linear regression, the observations are fit to a line with slope of $35.1 \pm 6.4 \mathrm{ppbv}\left(\sum \mathrm{AN}\right) / \mathrm{ppbv}\left(\mathrm{O}_{3}\right)$. We find observed $\sum \mathrm{ANs}$ and $\mathrm{O}_{3}$ are correlated with $R^{2}$ of 0.24 . The slope is in good agreement with reported morning values at Granite Bay, CA (Cleary et al., 2005), and between the morning and afternoon values found at La Porte, TX (Rosen et al., 2004). Horowitz et al. (2007) use the entire INTEX-NA/ICARTT summer 2004 dataset and find that observations of $\mathrm{O}_{3}$ versus

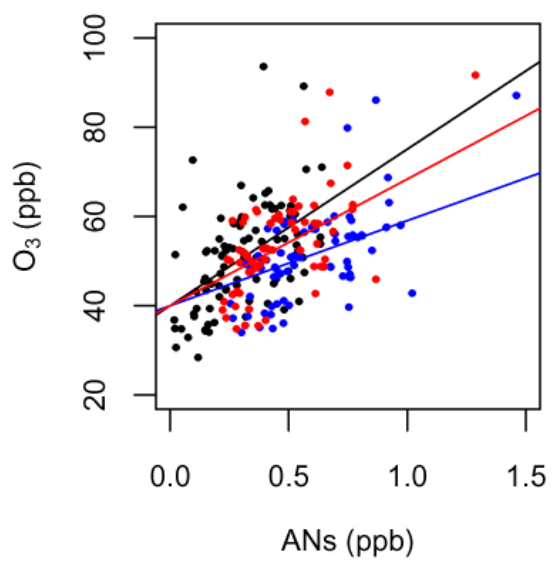

Fig. 5. Simulated fate of isoprene peroxy radicals in the IS and $\mathrm{E}$ (slow $\mathrm{HO}_{2}+\mathrm{RO}_{2}$ ) cases. Results are averaged over the entire modeling period for the southeastern US within $2 \mathrm{~km}$ of the surface. $\mathrm{ISOPO}_{2}$ refers to isoprene peroxy radicals formed from isoprene $+\mathrm{OH}$ reactions (Fig. 1a), and $\mathrm{NISOPO}_{2}$ refers to those formed from isoprene $+\mathrm{NO}_{3}$ reactions (Fig. 1b).

$\sum$ ANs are only weakly correlated $\left(R^{2}=0.12\right)$ with slope of 81.7. Compared to the correlation and slope reported by Horowitz et al. (2007), we find slightly stronger correlation and reduced slope (a factor of 2) using observations coincident with high isoprene concentrations. Following the methods of Rosen et al. (2004) and Cleary et al. (2005), the slope of 35.1 implies a $\sum$ ANs yield of $5.7 \%$. As the high isoprene observations are mostly found in the afternoon hours, it is expected that this net yield is lower than the actual yield, as some ANs are lost over the course of a day to deposition and photochemistry. Similar findings have been reported by Horowitz et al. (2007), where the inferred yield was about a factor of 2 lower than the isoprene nitrate yield from $\mathrm{OH}$ initiated chemistry.

The CMAQ simulated correlations of $\mathrm{O}_{3}$ versus $\sum$ ANs are compared with the observed relationship in Fig. 4. In comparison to the base simulation, the IS scheme greatly reduces the bias relative to the observed slope $(-19 \%$ vs. $-46 \%$ ). Slightly stronger correlations are found in the two model simulations (squared correlation coefficient of 0.33 ) compared to those from the observations.

In our analysis of $\mathrm{O}_{3}$ versus $\sum$ ANs correlations, the model predicts about $40 \% \sum$ ANs from sources other than isoprene (not shown). Prior measurements have inferred a substantial contribution of isoprene to $\sum$ ANs (Perring et al., 2009a; Beaver et al., 2012). Additional measurements of speciated organic nitrates are needed to better constrain the contribution of isoprene to the composition of $\sum$ ANs.

The IS mechanism with comprehensive isoprene chemistry more accurately simulates observed $\sum \mathrm{AN}, \mathrm{O}_{3}$, and $\mathrm{NO}_{\mathrm{x}}$. Nevertheless, substantial uncertainty remains in isoprene nitrate chemistry. In the following sections, we use observations to investigate and constrain these uncertainties. 

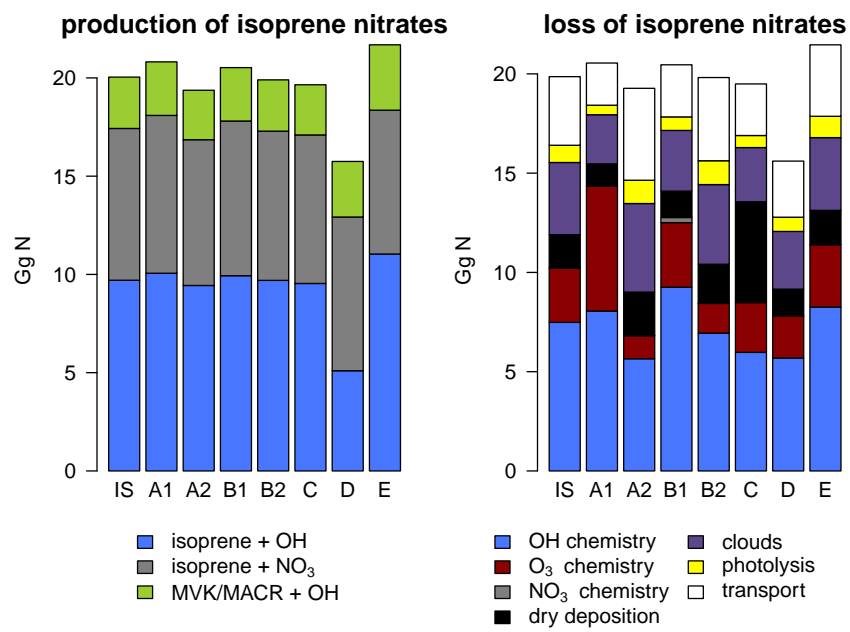

Fig. 6. Simulated production and loss processes for isoprene nitrates from the IS simulation and its sensitivity cases (listed in Table 2). Results are summarized over the entire modeling period for the southeastern US within $2 \mathrm{~km}$ of the surface.

Our examination of the isoprene peroxy radical fate and the sources and sinks of isoprene nitrates uses the IS simulation as a reference calculation to obtain a better understanding of the key processes.

\subsection{Fate of isoprene peroxy radicals}

To quantify the fate of isoprene peroxy radicals, we attribute the sinks to each chemical pathway using the CMAQ model results aggregated between the surface and $2 \mathrm{~km}$ in altitude and over the southeastern US. The results are shown in Fig. 5. For the peroxy radicals produced from $\mathrm{OH}$ reactions $\left(\mathrm{ISOPO}_{2}\right)$, the IS simulation suggests primary reactions with Pathway III, NO (44\%) and Pathway I, $\mathrm{HO}_{2}(40 \%)$. Isomerization plays a less important role $(9 \%)$ than reported in some previous studies (Peeters et al., 2009; Peeters and Müller, 2010; Archibald et al., 2010; Stavrakou et al., 2010), as we use the rate measured by Crounse et al. (2011). The $\mathrm{RO}_{2}+\mathrm{HO}_{2}$ reaction pathway has important implications as the epoxides formed from isoprene hydroxyhydroperoxide oxidation have been shown to be an important gas-phase precursor of SOA (Paulot et al., 2009b; Surratt et al., 2010; Froyd et al., 2010; Lin et al., 2012).

For peroxy radicals from $\mathrm{NO}_{3}$ reactions $\left(\mathrm{NISOPO}_{2}\right)$, the model predicts their fate is dominated by reactions with Pathway I, $\mathrm{HO}_{2}(43 \%)$ and Pathway II, $\mathrm{RO}_{2}$ (35\%, including $\mathrm{NISOPO}_{2}$ self-reactions $(6 \%)$, and their reactions with methyl peroxy radical $(9 \%)$, acetyl peroxy radical $(8 \%)$, and a peroxy radical operator $(\mathrm{RO} 2 \mathrm{C})(12 \%))$. The remaining portion is composed of reactions with Pathway III: $\mathrm{NO}(16 \%)$ and $\mathrm{NO}_{3}(7 \%)$. The dominance of reaction of $\mathrm{NISOPO}_{2}$ with $\mathrm{HO}_{2}$ is consistent with the laboratory and modeling results from Rollins et al. (2009) and can have significant impacts on the nighttime oxidants levels, as a re- cent study (Kwan et al., 2012) suggests a large yield (50\%) of $\mathrm{OH}$ formation from this pathway (not included in this study). Furthermore, recent laboratory work suggests that NISOPO2 self-reactions may form lower-volatility dimers that contribute to SOA (Ng et al., 2008; Kwan et al., 2012). In our simulation of the southeastern US, six percent of the NISOPO2 radicals undergo self reactions, which suggests this may be a relevant source of SOA but it is not a large sink of NISOPO2. It should be noted, however, that there are large uncertainties in the $\mathrm{RO}_{2}+\mathrm{RO}_{2}, \mathrm{RO}_{2}+\mathrm{HO}_{2}$, $\mathrm{RO}_{2}+\mathrm{NO}$, and $\mathrm{RO}_{2}+\mathrm{NO}_{3}$ reaction rates (Orlando and Tyndall, 2012), and better constraints from laboratory and field studies are needed to confirm the relative importance of these pathways.

\subsection{Production and loss of isoprene nitrates}

Using the same averaging domain over the southeastern US described in Sect. 3.2, the production and loss of isoprene nitrates are shown in Fig. 6 and Table 2. Modeling results from the IS case suggest a large fraction $(\sim 40 \%)$ of isoprene nitrates production occurs from isoprene oxidation by $\mathrm{NO}_{3}$, and subsequent reactions with $\mathrm{NO}, \mathrm{NO}_{3}, \mathrm{HO}_{2}$, and $\mathrm{RO}_{2}$. This branching ratio of sources from $\mathrm{NO}_{3}$ oxidation is generally consistent with the findings $(\sim 50 \%)$ from Horowitz et al. (2007); however, direct evidence for enhanced formation from this pathway is rare. Ambient observations have been largely limited to mono-functional alkyl nitrates and total alkyl nitrates (Buhr et al., 1990; Flocke et al., 1998; Rosen et al., 2004; Cleary et al., 2005; Day et al., 2009). Only in a few cases the diurnal profiles of specific individual multifunctional organic nitrates have been quantified (Grossenbacher et al., 2001, 2004; Beaver et al., 2012). More ambient measurements are needed to verify model predictions.

For the loss of total isoprene nitrates (ING), we count photochemical reactions as a loss process only if isoprene nitrates are converted to species that no longer retain the nitrate functional group. The model results show that ING loss is dominated by photooxidation by $\mathrm{OH}(38 \%)$ and $\mathrm{O}_{3}$ $(14 \%) . \mathrm{O}_{3}$ plays a less important role than $\mathrm{OH}$ despite reacting rapidly with isoprene nitrates (Lockwood et al., 2010), reflecting the lower $\mathrm{NO}_{\mathrm{x}}$ recycling efficiency we assumed in $\mathrm{O}_{3}+$ ISOPN reactions $\left(\sim 30 \%\right.$ in $\mathrm{O}_{3}+$ ISOPN versus $\sim 60 \%$ in $\mathrm{OH}+\mathrm{ISOPN}$ reactions). The additional loss consists of dry deposition $(8 \%)$ and cloud processes $(18 \%$, i.e., wet deposition and convective mixing), photolysis (4\%), and advection/diffusion out of the modeling subdomain (17\%). The large contribution from photooxidation is consistent with findings by Shepson et al. (1996), Ito et al. (2007), Perring et al. (2009a), and Paulot et al. (2012). In contrast, Horowitz et al. (2007) concludes that dry deposition is the main sink. The discrepancy is partly due to a faster dry deposition velocity (as of $\mathrm{HNO}_{3}$ ) used by Horowitz et al. (2007) and the fact that second-generation isoprene nitrates are assumed to be removed only by deposition processes in that study. The 
IS simulation also suggests there are large differences in the daytime versus nighttime lifetime of isoprene nitrates; the isoprene nitrates have a longer lifetime at night.

$\mathrm{ING}_{0}, \mathrm{ING}_{1}$, and $\mathrm{ING}_{2}$ attribute $16 \%, 30 \%$, and $11 \%$, respectively, to $\sum$ ANs concentrations, with the remaining $(\sim 40 \%)$ from sources other than isoprene (Fig. S2, Supplement). Comparing the relative role played by these different generations of isoprene nitrate species (not shown), $\mathrm{ING}_{0}$ and $\mathrm{ING}_{1}$ account for about $40 \%$ and $50 \%$ of the total loss of ING (excluding advection/diffusion), respectively. The large contribution from $\mathrm{ING}_{1}$ is due to its large fraction in the ING composition and also the fact that even though $\mathrm{ING}_{1}$ is longer-lived than $\mathrm{ING}_{0}$ (daytime lifetime $\sim 6.2 \mathrm{~h}$ versus $\sim 1.2 \mathrm{~h}$ ), it is assumed to release $\mathrm{NO}_{\mathrm{x}}$ entirely during photooxidation, whereas a significant portion of $\mathrm{ING}_{0}$ $(\sim 70 \%)$ is assumed to maintain the nitrate functional group in its reactions with $\mathrm{OH}, \mathrm{O}_{3}$, and $\mathrm{NO}_{3}$. Being much longerlived (daytime lifetime about $18 \mathrm{~h}$ ) and accounting for a small fraction of ING, $\mathrm{ING}_{2}$ contributes only $7 \%$ of the total loss, and may play an important role in the transport of $\mathrm{NO}_{\mathrm{x}}$ to remote regions and the free troposphere.

\subsection{Sensitivity simulations and constraints with INTEX-NA/ICARTT data}

In the previous sections, we have shown the peroxy radical fate as well as production and loss of isoprene nitrates from the IS simulation. Here we examine the sensitivity of model results to the most important uncertainties in our current understanding of isoprene nitrate chemistry, including the yield from the $\mathrm{OH} / \mathrm{NO}$ reaction pathway, $\mathrm{NO}_{\mathrm{x}}$ recycling efficiency from $\mathrm{ING}_{0}$, dry deposition rate, and $\mathrm{RO}_{2}+\mathrm{HO}_{2}$ reaction rate (Table 2 and Figs. 1, 5, and 6).

\subsubsection{Sensitivity simulations}

A. Daytime $\mathrm{NO}_{\mathrm{x}}$ recycling: when $\mathrm{ING}_{0}$ reacts with $\mathrm{OH}, \mathrm{O}_{3}$, and $\mathrm{NO}_{3}$, it is uncertain whether they will maintain the nitrate functional group or release $\mathrm{NO}_{\mathrm{x}}$ (Paulson and Seinfeld, 1992; Giacopelli et al., 2005; Paulot et al., 2009a). In the IS simulation, we use the recycling efficiency $(\sim 60 \%)$ from Paulot et al. (2009a) for the ISOPN+OH pathway. Since little is known about the recycling efficiency from ISOPN $+\mathrm{O}_{3}$ reactions and from nitrates formed from isoprene $+\mathrm{NO}_{3}$ reactions, we derive the likely products largely based on the SAPRC mechanism generation system. We investigate the uncertainty due to recycling efficiency separately for $\mathrm{ING}_{0}$ formed from the $\mathrm{OH}$ and $\mathrm{NO}_{3}$ pathways. When recycling is completely turned off, we assume an even split in production of $\mathrm{ING}_{1}$ (represented by RNO3I) and $\mathrm{ING}_{2}$ (represented by PROPNN/PROPNNB for $\mathrm{OH} / \mathrm{NO}_{3}$ pathways).

When $100 \%$ recycling efficiency is assumed for $\mathrm{ING}_{0}$ formed from isoprene oxidation by $\mathrm{OH}$ (run $\mathrm{A} 1$ ), the overall recycling efficiency increases to $\sim 70 \%$. Isoprene nitrates production increases slightly $(4 \%)$ as a result of in- creased $\mathrm{NO}_{\mathrm{x}}$, and therefore increases in the fraction of the peroxy radicals reacting with NO. The fraction of isoprene nitrates (ING) lost via photooxidation increases from $\sim 55 \%$ in the IS simulation to $\sim 70 \%$ in the A1 case. Loss through $\mathrm{ING}_{0}$ increases by about a factor of 2 , causing a substantially reduced lifetime of ING ( $\sim 6$ hours to $\sim 4$ hours during the day). In contrast, when recycling of $\mathrm{NO}_{\mathrm{x}}$ is completely turned off for these hydroxy isoprene nitrates (run A2), the overall recycling efficiency is reduced to $\sim 10 \%$. Production of isoprene nitrates decreases slightly $(-3 \%)$ as a result of decreased $\mathrm{NO}_{\mathrm{x}}$ and thus a decrease in the fraction of the peroxy radicals reacting with NO. Loss via dry deposition and clouds becomes comparable to that via photooxidation, with each process accounting for 35-40\% of the total loss of ING. Loss through $\mathrm{ING}_{0}$ decreases by about a factor of 2 , and consequently the lifetime of ING increases to $\sim 10 \mathrm{~h}$ during the day.

B. Nighttime $N O_{\mathrm{x}}$ recycling: when $100 \%$ recycling of $\mathrm{NO}_{\mathrm{x}}$ is assumed for the $\mathrm{ING}_{0}$ formed from the isoprene oxidation by $\mathrm{NO}_{3}$ (run B1), the change is generally similar (though smaller) to trends in the simulation examining the daytime recycling efficiency (run A1). When the recycling is completely turned off (run B2), the overall effects on the production and loss are relatively small, as the IS scheme already assumes the nitrates formed from isoprene $+\mathrm{NO}_{3}$ reactions release little $\mathrm{NO}_{\mathrm{x}}$ while reacting with $\mathrm{OH}$ and $\mathrm{NO}_{3}$. The most significant change is found in the lifetime of ING at night, which increases by a factor of 2 . Note that we only examine the recycling of $\mathrm{NO}_{\mathrm{x}}$ from isoprene nitrates formed exclusively from $\mathrm{NO}_{3}$ oxidation (C5-nitrooxycarbonyl and C5-nitrooxyhydroperoxide), which accounts for $\sim 90 \%$ of isoprene nitrates production at night.

C. Dry deposition: in the IS run, $\mathrm{ING}_{0}$ and $\mathrm{ING}_{1}$ use Henry's law constants of $\mathrm{H}_{298}=1.7 \times 10^{4} \mathrm{M} \mathrm{atm}^{-1}$ (Ito et al., 2007) and $\mathrm{ING}_{2}$ use a value of $\mathrm{H}_{298}=10^{3} \mathrm{Matm}^{-1}$ (Sander, 1999) to estimate their loss by wet deposition. We assume the dry deposition velocity is equal to that of PAN ( $\sim 0.6 \mathrm{~cm} \mathrm{~s}^{-1}$ at daytime), which is on the slow side of measured values (Shepson et al., 1996; Farmer and Cohen, 2008). A sensitivity simulation (run C) is conducted to examine the effect of this uncertainty in dry deposition velocity in which we increase the rate to that of $\mathrm{HNO}_{3}\left(\sim 3 \mathrm{~cm} \mathrm{~s}^{-1}\right)$, considered to be an upper limit. In this simulation, we find that loss of ING via dry deposition increases from $8 \%$ to $26 \%$ of the total. Combined with removal by clouds, the deposition loss $(40 \%)$ becomes comparable to that of photooxidation $(47 \%)$. The lifetime of ING during the day also drops considerably (to $\sim 4 \mathrm{~h}$ ).

D. Isoprene nitrate yield: with a yield of $12 \%$ from $\mathrm{OH} / \mathrm{NO}$ reactions and $70 \%$ from $\mathrm{NO}_{3}$ reactions, the IS simulation finds that about $40 \%$ of isoprene nitrates are produced from the $\mathrm{NO}_{3}$ pathways. There have been a number of laboratory studies reporting the yield of the $\mathrm{OH} / \mathrm{NO}$ pathway, as mentioned previously. Holding the yield from the $\mathrm{NO}_{3}$ pathway constant, we conduct a sensitivity simulation (run D) 
with a yield of $6 \%$ from the $\mathrm{OH} / \mathrm{NO}$ pathway, and this reduces the total production of isoprene nitrates by $20 \%$. The change also results in increased relative importance of $\mathrm{NO}_{3}$ pathways, which accounts for half of isoprene nitrates.

E. $\mathrm{RO}_{2}+\mathrm{HO}_{2}$ reaction rate: in the IS case, the $\mathrm{RO}_{2}+\mathrm{HO}_{2}$ reaction rates increase with the size of the molecule, consistent with the laboratory measurements (Rowley et al., 1992; Jenkin and Hayman,1995; Boyd et al., 2003). To assess the effects of using a uniform reaction rate for this class of reactions (as has been assumed in numerous previous studies), a sensitivity simulation is conducted where we change the rates to the value used by the base run (about half of the rate used in the IS scheme for isoprene peroxy radicals at $298 \mathrm{~K}$ ). This change has a significant impact on the relative importance of $\mathrm{NO}$ and $\mathrm{HO}_{2}$ pathways for the peroxy radicals formed by isoprene reacting with $\mathrm{OH}\left(\mathrm{ISOPO}_{2}\right)$. With the reduced rate of $\mathrm{HO}_{2}+\mathrm{ISOPO}_{2}$, NO becomes the dominant channel $(\sim 50 \%)$ and $\mathrm{HO}_{2}$ accounts for only $\sim 25 \%$. As a result, isoprene nitrates production increases by $\sim 10 \%$. For the peroxy radicals $\left(\mathrm{NISOPO}_{2}\right)$ formed by isoprene reacting with $\mathrm{NO}_{3}$, the slower $\mathrm{RO}_{2}+\mathrm{HO}_{2}$ rates switch the relative importance of $\mathrm{HO}_{2}$ and $\mathrm{RO}_{2}$ pathways, but the role of $\mathrm{NO}$ and $\mathrm{NO}_{3}$ channels remains generally the same.

\subsubsection{Observational constraints}

From previous analysis (Sect. 3.1), we have shown that while the IS simulation has improved model performance for a range of species, there is still notable bias in terms of $\sum$ ANs and its correlation with $\mathrm{O}_{3}$. We also find uncertainties in the isoprene nitrate chemistry have a significant impact on their production and loss processes. Here we use observed $\sum$ ANs and $\mathrm{O}_{3}$ concentrations to further constrain these uncertainties.

In environments with high isoprene concentrations $(>500$ pptv), the slope of the correlation between $\sum$ ANs and $\mathrm{O}_{3}$ (Fig. 7) is best mimicked by the simulation with reduced isoprene nitrate yield (run D), while the two $100 \%$ recycling $\mathrm{NO}_{\mathrm{x}}$ cases (run $\mathrm{A} 1$ and $\mathrm{B} 1$ ) and the fast dry deposition case (run $\mathrm{C}$ ) also show reasonably good performance and fall within the uncertainty range. On the other hand, the simulation with $0 \% \mathrm{NO}_{\mathrm{x}}$ recycling from $\mathrm{ING}_{0}$ formed from the $\mathrm{OH} / \mathrm{NO}$ pathway (run A2) substantially degrades the performance, underpredicting the slope by about $40 \%$.

The simulations that have a slope of $\sum A N$ s versus $\mathrm{O}_{3}$ similar to the observations also show better agreement in terms of $\sum$ ANs concentrations. In environments with high isoprene concentrations ( $>500 \mathrm{pptv}$ ), the IS simulation shows $\sim 45 \%$ overestimation of the median $\sum$ ANs concentrations, while the base run substantially degrades the model performance with a bias of $\sim 90 \%$. Best agreement is achieved in the runs assuming $100 \%$ recycling of $\mathrm{NO}_{\mathrm{x}}$ from $\mathrm{ING}_{0}$ formed from isoprene oxidation by $\mathrm{OH}$ (run $\mathrm{A} 1$ ), using the isoprene nitrate yield of $6 \%$ from the $\mathrm{OH} / \mathrm{NO}$ pathway (run D), or using a fast dry deposition rate as $\mathrm{HNO}_{3}$ (run C).
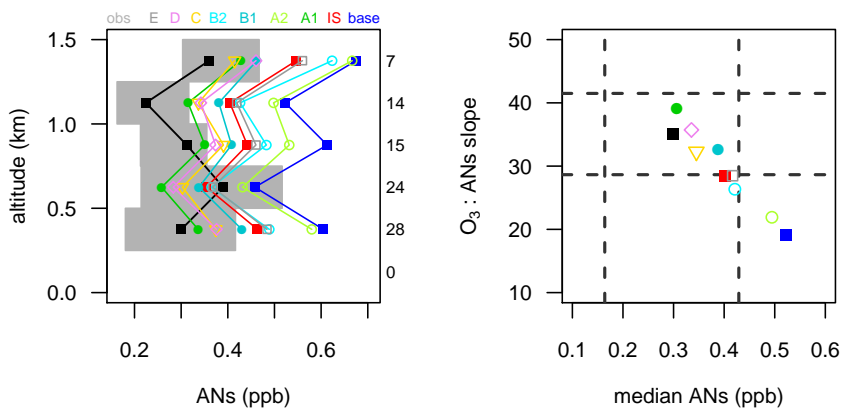

Fig. 7. Modeled and observed vertical profile of $\sum$ ANs median concentrations (left) and the slope of the $\mathrm{O}_{3}$ and $\sum$ ANs relationship (right). Data are selected with the same criteria as those in Fig. 4 (daytime observations within $2 \mathrm{~km}$ of the surface and with observed isoprene $>500 \mathrm{ppt}$ ). Left: The grey boxes show the interquartile ranges of observations. Numbers on the right side of the plot indicate data points in each vertical bin. Right: Uncertainty range of the observations is indicated by horizontal dashed lines (standard error of the fitted slope) and vertical dashed lines (interquartile values of $\sum$ ANs). (black square: observation; blue square: base; red square: IS; solid green circle: A1; open green circle: A2; solid blue circle: $\mathrm{B} 1$; open blue circle: $\mathrm{B} 2$; orange triangle: $\mathrm{C}$; purple diamond: $\mathrm{D}$; grey square: E).

When a recycling of $0 \%$ from $\mathrm{ING}_{0}$ oxidation is assumed (run A2), the agreement substantially worsens with predictions close to the base case. Note that a recent study by Crounse et al. (2012) suggests that methacrolein hydroxy peroxy radicals mostly undergo isomerization and decomposition without forming MACRN in the atmosphere. This, however, should only have minor effects on our conclusions as MACR and MVK together contribute 13-18\% of isoprene nitrates production in the model simulations.

In summary, the base case shows substantial overestimation of $\sum$ ANs concentrations and underestimation of the $\mathrm{O}_{3} / \sum$ ANs slope. The IS simulation improves both, though it still overpredicts $\sum$ ANs by $\sim 45 \%$ and underpredicts the $\mathrm{O}_{3} / \sum$ ANs slope by $20 \%$. The $\mathrm{NO}_{\mathrm{x}}$ recycling efficiency from $\mathrm{ING}_{0}$ formed from the $\mathrm{OH} / \mathrm{NO}$ pathway appears to have the largest impact on the model performance, followed by isoprene nitrate yield, dry deposition rate, and the $\mathrm{NO}_{\mathrm{x}}$ recycling efficiency from $\mathrm{ING}_{0}$ formed from the $\mathrm{NO}_{3}$ pathway. Improved agreement with the observations can be produced by reducing isoprene nitrate concentrations via any one of the following: (1) using a $6 \%$ yield of isoprene nitrates from the $\mathrm{OH} / \mathrm{NO}$ pathway; (2) allowing isoprene nitrates to dry deposit as rapidly as $\mathrm{HNO}_{3}$; (3) assuming a $\mathrm{NO}_{\mathrm{x}}$ recycling efficiency of $100 \%$ from $\mathrm{ING}_{0}$ formed from $\mathrm{OH}$ oxidation; or (4) assuming a $\mathrm{NO}_{\mathrm{x}}$ recycling efficiency of $100 \%$ from $\mathrm{ING}_{0}$ formed from $\mathrm{NO}_{3}$ oxidation. On the other hand, assuming $0 \% \mathrm{NO}_{\mathrm{x}}$ recycling from $\mathrm{ING}_{0}$ formed from $\mathrm{OH}$ oxidation shows substantially degraded performance, similar to that of the base run. Note that we evaluate the uncertainties in isoprene nitrate chemistry by varying one parameter 


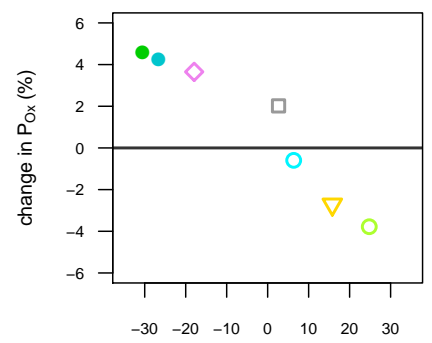

change in $D_{\text {ING }}(\%)$

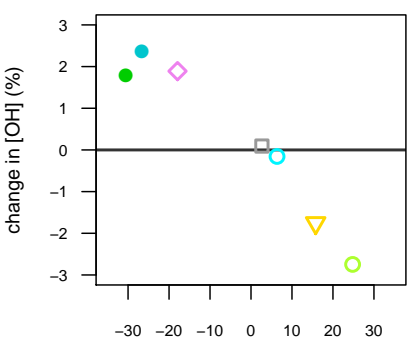

change in $\mathrm{D}_{\mathrm{ING}}(\%)$

Fig. 8. Correlations between $D_{\mathrm{ING}}$ and $P_{\mathrm{Ox}}$ (left) and correlations between $D_{\mathrm{ING}}$ and $\mathrm{OH}$ concentrations (right) from the IS simulation and its sensitivity cases. Results are summarized over the entire modeling period for the southeastern US within $2 \mathrm{~km}$ of the surface. Symbols represent the same sensitivity cases as those described in Fig. 7.

at a time, and therefore combinations of changes might further improve the comparison with observations. For example, even though the simulation with $0 \% \mathrm{NO}_{\mathrm{x}}$ recycling efficiency for $\mathrm{ING}_{0}$ formed from $\mathrm{NO}_{3}$ oxidation shows some underestimation of the $\mathrm{O}_{3} / \sum$ ANs slope, it might result in acceptable performance if the isoprene nitrate yield is reduced or a fast dry deposition rate is used. Nevertheless, we find similar daytime lifetimes of isoprene nitrates $(\sim 4 \mathrm{~h}$ for the $12 \%$ yield cases and $\sim 6 \mathrm{~h}$ for the $6 \%$ yield case) in both simulations that show good agreement with observations. However, our CMAQ simulation suggests that non-isoprene organic nitrates are $40 \%$ of the $\sum$ ANs. Errors in the nonisoprene ANs may influence these results.

\subsection{Impacts on $\mathrm{OH}$ and $\mathrm{Ox}$}

The IS scheme has significant impact on $\mathrm{NO}_{\mathrm{x}}, \mathrm{NO}_{3}$, and biogenic SOA concentrations as compared to the base case. We also find uncertainties in the IS scheme can have large effects on the sources and sinks of isoprene nitrates. Here we further examine the sensitivity of $\mathrm{O}_{3}$ and $\mathrm{OH}$ to these uncertainties in the isoprene nitrate chemistry.

We start our investigation by quantifying the variations in fate of $\mathrm{NO}_{\mathrm{x}}$ due to the uncertainties in isoprene nitrate chemistry. Using the methodology of Paulot et al. (2012), the local net removal of $\mathrm{NO}_{\mathrm{x}}$ by isoprene nitrates, $D_{\mathrm{ING}}$, is defined as

$D_{\mathrm{ING}}=P_{\mathrm{ING} 0}+P_{\mathrm{ING} 1 \text { new }}-L_{\mathrm{ING} 1}-L_{\mathrm{ING} 2}-\alpha \times L_{\mathrm{ING} 0}$,

where $P_{\mathrm{ING} 0}$ represents photochemical production of firstgeneration isoprene nitrates, $P_{\text {ING1_new }}$ represents production of isoprene nitrates from MVK and MACR, $\alpha \times L_{\mathrm{ING} 0}$ represents $\mathrm{NO}_{\mathrm{x}}$ recycled from $\mathrm{ING}_{0}$, and $L_{\mathrm{ING} 1}$ and $L_{\mathrm{ING} 2}$ represent photochemical loss of $\mathrm{ING}_{1}$ and $\mathrm{ING}_{2}$. Figure 8 shows that changes in $\mathrm{O}_{\mathrm{x}}\left(=\mathrm{O}_{3}+\mathrm{NO}_{2}\right)$ production are well correlated with changes in the amount of $\mathrm{NO}_{\mathrm{x}}$ removed by isoprene nitrate chemistry $\left(D_{\mathrm{ING}}\right)$ in the southeastern United States, consistent with the findings of Paulot et al. (2012).

The uncertainties in the isoprene nitrate chemistry can impact the production of $\mathrm{O}_{\mathrm{x}}\left(\mathrm{P}\left(\mathrm{O}_{\mathrm{x}}\right)\right)$ by about $10 \%$, while the sensitivity of $\mathrm{P}\left(\mathrm{O}_{\mathrm{x}}\right)$ to changes in $D_{\mathrm{ING}}\left(\Delta \mathrm{P}\left(\mathrm{O}_{\mathrm{x}}\right) / \Delta D_{\mathrm{ING}}\right)$ is about $-15 \%$. The simulation using slower $\mathrm{RO}_{2}+\mathrm{HO}_{2}$ rates behaves slightly differently from the other models runs, as an increased fraction of $\mathrm{RO}_{2}$ reacts with $\mathrm{NO}$, and consequently increased $\mathrm{O}_{\mathrm{x}}$ production also plays a role. Paulot et al. (2012) studied the effects of these uncertainties in tropical regions (South America, Southeast Asia, and Africa) with a range of $\mathrm{NO}_{\mathrm{x}}$ emissions. Compared to their results, we find $\Delta \mathrm{P}\left(\mathrm{O}_{\mathrm{x}}\right) / \Delta D_{\text {ING }}$ in our study region is similar to tropical locations which have the highest $\mathrm{NO}_{\mathrm{x}}$ emissions, i.e., Southeast Asia or Africa during the biomass burning season. Much greater impact is reported by Paulot et al. (2012) for South America, which is characterized by very low NO and therefore larger ozone production efficiency. Furthermore, the $\mathrm{NO}_{\mathrm{x}}$ recycling efficiency from $\mathrm{ING}_{0}$ appears to have the largest impact on ozone production in our study region, whereas more equally shared importance between deposition velocity, $\mathrm{NO}_{\mathrm{x}}$ recycling efficiency, and isoprene nitrate yield is indicated by the results of Paulot et al. (2012) for South America. The differences are likely a result of higher $\mathrm{OH}$ and $\mathrm{O}_{3}$ concentrations, and therefore increased importance of photochemical loss in our study area.

Changes in $\mathrm{OH}$ concentrations are also well correlated with changes in $D_{\mathrm{ING}}$, and the uncertainties in isoprene nitrate chemistry can impact $\mathrm{OH}$ concentrations by $\sim 6 \%$. The results show $\mathrm{OH}$ concentrations generally increase as $D_{\mathrm{ING}}$ decreases. However, further reduction of $D_{\mathrm{ING}}$ also increases the formation of $\mathrm{HNO}_{3}$ by reaction of $\mathrm{NO}_{2}+\mathrm{OH}$, which removes $\mathrm{NO}_{\mathrm{x}}$ and $\mathrm{OH}$ simultaneously (case $\mathrm{A} 1$ ). Compared to the changes from the base to the IS scheme $(\sim 30 \%)$, we find less of an impact on $\mathrm{OH}$ due to the uncertainties in isoprene nitrate chemistry. This is because the increase in $\mathrm{OH}$ in the IS scheme is primarily driven by increased $\mathrm{HO}_{\mathrm{x}}$ production rather than changes in $\mathrm{NO}_{\mathrm{x}}$.

\section{Conclusions}

Air quality in the southeastern United States is influenced by the interplay between abundant isoprene emissions and anthropogenic pollutants. We incorporate recent advances in our understanding of isoprene oxidation chemistry into the SAPRC-07 chemical mechanism within the CMAQ model, including isoprene nitrates formation and oxidation, epoxide formation, and isoprene peroxy radical isomerization. We use observations from the 2004 INTEX-NA/ICARTT field campaign to evaluate model performance and constrain the uncertainties in the isoprene nitrate chemistry.

We find the new model improves the simulation of the aircraft observations for a range of species. We find that most isoprene nitrates are relatively short-lived and prone to returning $\mathrm{NO}_{\mathrm{x}}$, and thus produce increased $\mathrm{NO}_{\mathrm{x}}(4-9 \%)$ and $\mathrm{O}_{3}(2 \mathrm{ppbv})$ in the southeastern US. OH concentrations 
increase by $\sim 30 \%$ primarily as a result of increased $\mathrm{HO}_{\mathrm{x}}$ production. Laboratory studies have also observed $\mathrm{OH}$ reformation from $\mathrm{RO}_{2}+\mathrm{HO}_{2}$ reactions, with differing yields, depending on the source of peroxy radicals (Hasson et al., 2004; Jenkin et al., 2007; Dillon and Crowley, 2008; Taraborrelli et al., 2012). In this work we have considered $\mathrm{OH}$ reformation from isoprene peroxy radicals (Paulot et al., 2009b, Taraborrelli et al., 2012; Liu et al., 2012), but not from acyl peroxy radicals and $\beta$-oxo peroxy radicals. Assuming $\mathrm{OH}$ yield of up to $50 \%$, recent modeling work has shown that these reactions increase $\mathrm{OH}$ concentrations by $5-40 \%$ (Pugh et al., 2010; Kubistin et al., 2010; Stavrakou et al., 2010; Stone et al., 2011). We would expect an additional increase in $\mathrm{OH}$ if this source of $\mathrm{OH}$ were included in the IS mechanism.

The increase in oxidants $\left(\mathrm{OH}, \mathrm{O}_{3}\right.$, and $\left.\mathrm{NO}_{3}\right)$ causes concentrations of biogenic SOA to increase by $15 \%$. Future work will integrate the detailed representation of isoprene oxidation described here with recent advances elucidating the chemical origins of isoprene SOA (Surratt et al., 2010; Lin et al., 2012).

$\mathrm{HO}_{2}$ reactions with isoprene peroxy radical are estimated to account for $\sim 40 \%$ of total reactions during both daytime and nighttime oxidation, highlighting the importance of a better understanding of the oxidation products from this pathway even for a region with elevated $\mathrm{NO}_{\mathrm{x}}$ concentrations. The isoprene peroxy radical isomerization accounts for $\sim 10 \%$ of the total.

We examine the sensitivity of our model results to the key assumptions in the isoprene nitrate chemistry, including the yield from the $\mathrm{OH} / \mathrm{NO}$ pathway, $\mathrm{NO}_{\mathrm{x}}$ recycling efficiency from first generation isoprene nitrates, dry deposition rate, and $\mathrm{RO}_{2}+\mathrm{HO}_{2}$ reaction rates. Constrained by observed $\sum$ ANs and their correlation with $\mathrm{O}_{3}$, reasonably good agreement can be achieved using a range of isoprene nitrate yields and daytime lifetimes: between $6 \%, \sim 6 \mathrm{~h}$ and $12 \%, \sim 4 \mathrm{~h}$.

Uncertainties in the isoprene nitrate chemistry can impact ozone production by $\sim 10 \%$ and $\mathrm{OH}$ concentrations by $\sim 6 \%$ in the southeastern United States. The effects are wellcorrelated with the changes in the net amount of $\mathrm{NO}_{\mathrm{x}}$ removed by isoprene nitrate chemistry, consistent with findings from Paulot et al. (2012). The uncertainties in $\mathrm{NO}_{\mathrm{x}}$ recycling efficiency appear to have a larger impact than uncertainties in isoprene nitrate yield and dry deposition velocity.

We find $40-50 \%$ of the isoprene nitrates are formed from isoprene $+\mathrm{NO}_{3}$ reactions, consistent with previous findings (Horowitz et al., 2007). Substantial uncertainty exists in the nighttime isoprene nitrate chemistry and peroxy radical fate, and further studies are required to elucidate the oxidation pathways and products. We find that photooxidation accounts for about half of the total loss of isoprene nitrates even when these compounds dry deposit as rapidly as $\mathrm{HNO}_{3}$. A significant fraction of the loss proceeds via production of secondary oxidation products whose fate remain very uncertain.

In regions at the confluence of biogenic emissions and anthropogenic pollution, accurate simulations of the ozone and secondary organic aerosol depend on representing the isoprene oxidation chemistry accurately. Further progress depends on improved understanding of isoprene oxidation pathways, rate of $\mathrm{NO}_{\mathrm{x}}$ recycling from isoprene nitrates, and the fate of the secondary, tertiary, and further oxidation products of isoprene.

\section{Supplementary material related to this article is available online at: http://www.atmos-chem-phys.net/13/ 8439/2013/acp-13-8439-2013-supplement.pdf.}

Acknowledgements. We thank the entire INTEX-NA/ICARTT team for the use of their measurement data. We also thank Barron Henderson, Melinda Beaver, Tad Kleindienst, and John Crounse for helpful conversations. This research was supported by the National Research Council Research Associateship Program pursued at the US Environmental Protection Agency. Fabien Paulot acknowledges support from a NASA Earth and Space Science fellowship. Disclaimer: although this article has been reviewed by the EPA and approved for publication, it does not necessarily reflect EPA policies or views.

Edited by: J. Thornton

\section{References}

Appel, K. W., Foley, K. M., Bash, J. O., Pinder, R. W., Dennis, R. L., Allen, D. J., and Pickering, K.: A multi-resolution assessment of the Community Multiscale Air Quality (CMAQ) model v4.7 wet deposition estimates for 2002-2006, Geosci. Model Dev., 4, 357-371, doi:10.5194/gmd-4-357-2011, 2011

Archibald, A. T., Cooke, M. C., Utembe, S. R., Shallcross, D. E., Derwent, R. G., and Jenkin, M. E.: Impacts of mechanistic changes on $\mathrm{HO}_{\mathrm{x}}$ formation and recycling in the oxidation of isoprene, Atmos. Chem. Phys., 10, 8097-8118, doi:10.5194/acp-108097-2010, 2010.

Barnes, I., Bastian, V., Becker, K. H., and Tong, Z.: Kinetics and products of the reactions of $\mathrm{NO}_{3}$ with monoalkenes, dialkenes, and monoterpenes, J. Phys. Chem., 94, 2413-2419, 1990.

Barnes, I., Becker, K. H., and Tong, Z.: Near UV absorption spectra and photolysis products of difunctional organic nitrates: possible importance as $\mathrm{NO}_{\mathrm{x}}$ reservoirs, J. Atmos. Chem. 17, 353-373, 1993.

Beaver, M. R., Clair, J. M. St., Paulot, F., Spencer, K. M., Crounse, J. D., LaFranchi, B. W., Min, K. E., Pusede, S. E., Wooldridge, P. J., Schade, G. W., Park, C., Cohen, R. C., and Wennberg, P. O.: Importance of biogenic precursors to the budget of organic nitrates: observations of multifunctional organic nitrates by CIMS and TD-LIF during BEARPEX 2009, Atmos. Chem. Phys., 12, 5773-5785, doi:10.5194/acp-12-5773-2012, 2012.

Berndt, T. and Boge, O.: Gas-phase reaction of $\mathrm{NO}_{3}$ radicals with isoprene: A kinetic and mechanistic study, Int. J. Chem. Kinet., 29, 755-765, 1997. 
Boyd, A. A., Flaud, P.-M., Daugey, N., and Lesclaux, R.: Rate constants for $\mathrm{RO}_{2}+\mathrm{HO}_{2}$ reactions measured under a large excess of $\mathrm{HO}_{2}$, J. Phys. Chem. A, 107, 818-821, doi:10.1021/jp026581r, 2003.

Brown, S. S., deGouw, J. A., Warneke, C., Ryerson, T. B., Dubé, W. P., Atlas, E., Weber, R. J., Peltier, R. E., Neuman, J. A., Roberts, J. M., Swanson, A., Flocke, F., McKeen, S. A., Brioude, J., Sommariva, R., Trainer, M., Fehsenfeld, F. C., and Ravishankara, A. R.: Nocturnal isoprene oxidation over the Northeast United States in summer and its impact on reactive nitrogen partitioning and secondary organic aerosol, Atmos. Chem. Phys., 9, 3027-3042, doi:10.5194/acp-9-3027-2009, 2009.

Buhr, M. P., Parrish, D. D., Norton, R. B., Fehsenfeld, F. C., Sievers, R. E., and Roberts, J. M.: Contribution of organic nitrates to the total reactive nitrogen budget at a rural eastern US site, J. Geophys. Res., 95, 9809-9816, 1990.

Butler, T. M., Taraborrelli, D., Brühl, C., Fischer, H., Harder, H., Martinez, M., Williams, J., Lawrence, M. G., and Lelieveld, J.: Improved simulation of isoprene oxidation chemistry with the ECHAM5/MESSy chemistry-climate model: lessons from the GABRIEL airborne field campaign, Atmos. Chem. Phys., 8, 4529-4546, doi:10.5194/acp-8-4529-2008, 2008.

Byun, D. and Schere, K. L.: Review of the governing equations, computational algorithms, and other components of the Models3 Community Multiscale Air Quality (CMAQ) modeling system, Appl. Mech. Rev., 59, 51-77, 2006.

Carlton, A. G. and Baker, K. R.: Photochemical modeling of the Ozark isoprene volcano: MEGAN, BEIS, and their impacts on air quality predictions, Environ. Sci. Technol., 45, 4438-4445, doi:10.1021/es200050x, 2011.

Carlton, A. G., Bhave, P. V., Napelenok, S. L., Edney, E. O., Sarwar, G., Pinder, R. W., Pouliot, G. A., and Houyoux, M.: Model Representation of Secondary Organic Aerosol in CMAQv4.7, Environ. Sci. Technol., 44, 8553-8560, 2010.

Carter, W. P. L.: Documentation of the SAPRC-99 Chemical Mechanism for VOC Reactivity Assessment, Final report to the California Air Resources Board, Contracts 92-329 and 95-308, 8 May 2000 (available at: http://www.cert.ucr.edu/ carter/absts. htm $\{\#\}$ saprc99), 2000.

Carter, W. P. L.: Development of the SAPRC-07 Chemical Mechanism, Atmos. Environ., 44, 5324-5335, 2010a.

Carter, W. P. L.: Development of the SAPRC-07 chemical mechanism and updated ozone reactivity scales, Report to the California Air Resources Board, Contract No. 03-18, 06-408, and 07-730, 27 January 2010b (available at: http://www.engr.ucr.edu/ $\sim$ carter/SAPRC/), 2010 b.

Chen, X., Hulbert, D., and Shepson, P. B.: Measurement of the organic nitrate yield from $\mathrm{OH}$ reaction with isoprene, J. Geophys. Res., 103, 25563-25568, doi:10.1029/98JD01483, 1998.

Chuong, B. and Stevens, P. S.: Measurements of the kinetics of the $\mathrm{OH}$-initiated oxidation of isoprene, J. Geophys. Res., 107, 4162, doi:10.1029/2001JD000865, 2002.

Claeys, M., Graham, B., Vas, G.,Wang,W., Vermeylen, R., Pashynska, V., Cafmeyer, J., Guyon, P., Andreae, M. O., Araxo, P., and Maenhaut, W.: Formation of secondary organic aerosols through photooxidation of isoprene, Science, 303, 1173-1176, 2004.

Cleary, P. A., Murphy, J. G., Wooldridge, P. J., Day, D. A., Millet, D. B., McKay, M., Goldstein, A. H., and Cohen, R. C.: Observa- tions of total alkyl nitrates within the Sacramento Urban Plume, Atmos. Chem. Phys. Discuss., 5, 4801-4843, doi:10.5194/acpd5-4801-2005, 2005.

Crounse, J. D., Paulot, F., Kjaergaard, H. G., and Wennberg, P. O.: Peroxy radical isomerization in the oxidation of isoprene, Phys. Chem. Chem. Phys., 13, 13607-13613, doi:10.1039/c1cp21330j, 2011.

Crounse, J. D., Knap, H. C., Ørnsø, K. B., Jørgensen, S., Paulot, F., Kjaergaard, H. G., and Wennberg, P. O.: Atmospheric fate of methacrolein. 1. Peroxy radical isomerization following addition of $\mathrm{OH}$ and $\mathrm{O}_{2}$, J. Phys. Chem. A, 116, 5756-5762, doi:10.1021/jp211560u, 2012.

Day, D. A., Wooldridge, P. J., Dillon, M. B., Thornton, J. A., and Cohen, R. C.: A thermal dissociation laser-induced fluorescence instrument for in situ detection of $\mathrm{NO}_{2}$, peroxy nitrates, alkyl nitrates, and $\mathrm{HNO}_{3}$, J. Geophys. Res., 107, 4046, doi:10.1029/2003JD003685, 2002.

Day, D. A., Farmer, D. K., Goldstein, A. H., Wooldridge, P. J., Minejima, C., and Cohen, R. C.: Observations of $\mathrm{NO}_{\mathrm{x}}, \Sigma \mathrm{PNs}$, $\Sigma$ ANs, and $\mathrm{HNO}_{3}$ at a Rural Site in the California Sierra Nevada Mountains: summertime diurnal cycles, Atmos. Chem. Phys., 9, 4879-4896, doi:10.5194/acp-9-4879-2009, 2009.

Dillon, T. J. and Crowley, J. N.: Direct detection of OH formation in the reactions of $\mathrm{HO}_{2}$ with $\mathrm{CH}_{3} \mathrm{C}(\mathrm{O}) \mathrm{O}_{2}$ and other substituted peroxy radicals, Atmos. Chem. Phys., 8, 4877-4889, doi:10.5194/acp-8-4877-2008, 2008.

Edney, E. O., Kleindienst, T. E., Jaoui, M., Lewandowski, M., Offenberg, J. H.,Wang,W., and Claeys, M.: Formation of 2-methyl tetrols and 2-methylglyceric acid in secondary organic aerosol from laboratory irradiated isoprene/ $\mathrm{NO}_{\mathrm{x}} / \mathrm{SO}_{2} /$ air mixtures and their detection in ambient $\mathrm{PM}_{2.5}$ samples collected in the eastern United States, Atmos. Environ., 39, 5281-5289, 2005.

Farmer, D. K. and Cohen, R. C.: Observations of $\mathrm{HNO}_{3}, \Sigma \mathrm{AN}$, $\Sigma \mathrm{PN}$ and $\mathrm{NO}_{2}$ fluxes: evidence for rapid $\mathrm{HO}_{\mathrm{x}}$ chemistry within a pine forest canopy, Atmos. Chem. Phys., 8, 3899-3917, doi:10.5194/acp-8-3899-2008, 2008.

Fehsenfeld, F. C., Ancellet, G., Bates, T. S., Goldstein, A. H., Hardesty, R. M., Honrath, R., Law, K. S., Lewis, A. C., Leaitch, R., McKeen, S., Meagher, J., Parrish, D. D., Pszenny, A. A., Russell, P. B., Schlager, H., Seinfeld, J., Talbot, R., and Zbinden, R.: International Consortium for Atmospheric Research on Transport and Transformation (ICARTT): North America to Europe Overview of the 2004 summer field study, J. Geophys. Res., 111, D23S01, doi:10.1029/2006JD007829, 2006.

Flocke, F., Volz-Thomas, A., Buers, H. J., Patz, W., Garthe, H. J., and Kley, D.: Long-term measurements of alkyl nitrates in southern Germany 1. General behavior and seasonal and diurnal variation, J. Geophys. Res., 103, 5729-5746, 1998.

Foley, K. M., Roselle, S. J., Appel, K. W., Bhave, P. V., Pleim, J. E., Otte, T. L., Mathur, R., Sarwar, G., Young, J. O., Gilliam, R. C., Nolte, C. G., Kelly, J. T., Gilliland, A. B., and Bash, J. O.: Incremental testing of the Community Multiscale Air Quality (CMAQ) modeling system version 4.7, Geosci. Model Dev., 3, 205-226, doi:10.5194/gmd-3-205-2010, 2010.

Froyd, K. D., Murphy, S. M., Murphy, D. M., de Gouw, J. A., Eddingsaas, N. C., and Wennberg, P. O.: Contribution of isoprenederived organosulfates to free tropospheric aerosol mass, Proc. Nat. Acad. of Science of the USA, 107, 21360-21365, 2010. 
Fuchs, H., Bohn, B., Hofzumahaus, A., Holland, F., Lu, K. D., Nehr, S., Rohrer, F., and Wahner, A.: Detection of $\mathrm{HO}_{2}$ by laserinduced fluorescence: calibration and interferences from $\mathrm{RO}_{2}$ radicals, Atmos. Meas. Tech., 4, 1209-1225, doi:10.5194/amt4-1209-2011, 2011.

Giacopelli, P., Ford, K., Espada, C., and Shepson, P. B.: Comparison of the measured and simulated isoprene nitrate distributions above a forest canopy, J. Geophys. Res., 110, D01304, doi:10.1029/2004JD005123, 2005.

Grell, G. A., Dudhia, J., and Stauffer, D. R.: A description of the fifth-generation Penn State/NCAR mesoscale model (MM5), National Center for Atmospheric Research, Boulder, CO, USA, NCAR/TN-398+STR, 122 pp., 1994.

Griffin, R. J., Cocker, D. R., Flagan, R. C., and Seinfeld, J. H.: Organic aerosol formation from the oxidation of biogenic hydrocarbons, J. Geophys. Res., 104, 3555-3567, 1999.

Grossenbacher, J. W., Couch, T., Shepson, P. B., Thornberry, T., Witmer-Rich, M., Carroll, M. A., Faloona, I., Tan, D., Brune,W., Ostling, K., and Bertman, S.: Measurements of isoprene nitrates above a forest canopy, J. Geophys. Res., 106, 24429- 24438, 2001.

Grossenbacher, J. W., Barket, D. J., Shepson, P. B., Carroll, M. A., Olszyna, K., and Apel, E.: A comparison of isoprene nitrate concentrations at two forest-impacted sites, J. Geophys. Res., 109, D11311, doi:10.1029/2003JD003966, 2004.

Guenther, A., Karl, T., Harley, P., Wiedinmyer, C., Palmer, P. I., and Geron, C.: Estimates of global terrestrial isoprene emissions using MEGAN (Model of Emissions of Gases and Aerosols from Nature), Atmos. Chem. Phys., 6, 3181-3210, doi:10.5194/acp-63181-2006, 2006.

Hasson, A. S., Tyndall, G. S., and Orlando, J. J.: A product yield study of the reaction of $\mathrm{HO}_{2}$ radicals with ethyl peroxy $\left(\mathrm{C}_{2} \mathrm{H}_{5} \mathrm{O}_{2}\right)$, acetyl peroxy $\left(\mathrm{CH}_{3} \mathrm{C}(\mathrm{O}) \mathrm{O}_{2}\right)$, and acetonyl peroxy $\left(\mathrm{CH}_{3} \mathrm{C}(\mathrm{O}) \mathrm{CH}_{2} \mathrm{O}_{2}\right)$ radicals, J. Phys. Chem. A, 108, 5979-5989, 2004.

Horowitz, L. W., Fiore, A. M., Milly, G. P., Cohen, R. C., Perring, A., Wooldridge, P. J., Hess, P. G., Emmons, L. K., and Lamarque, $\mathrm{J}$.: Observational constraints on the chemistry of isoprene nitrates over the eastern United States, J. Geophys. Res., 112, D01304, doi:10.1029/2006JD007747, 2007.

Houyoux, M. R., Vukovich, J. M., Coats, C. J. Jr., and Wheeler, N. J. M.: Emission inventory development and processing for the Seasonal Model for Regional Air Quality (SMRAQ) project, J. Geophys. Res., 105, 9079-9090, 2000.

Hutzell, W. T., Luecken, D. J., Appel, K. W., and Carter, W. P. L.: Interpreting predictions from the SAPRC07 mechanism based on regional and continental simulations, Atmos. Environ., 46, 417429, 2012.

Ito, A., Sillman, S., and Penner, J. E.: Effects of additional nonmethane volatile organic compounds, organic nitrates, and direct emissions of oxygenated organic species on global tropospheric chemistry, J. Geophys. Res., 112, D06309, doi:10.1029/2005JD006556, 2007.

Jenkin, M. E. and Hayman, G. D.: Kinetics of reactions of primary, secondary and tertiary beta-hydroxy peroxyl radicals: application to isoprene degradation, J. Chem. Soc., Faraday Trans. 91, 19111922, 1995.

Jenkin, M. E., Hurley, M. D., and Wallington, T. J.: Investigation of the radical product channel of the $\mathrm{CH}_{3} \mathrm{C}(\mathrm{O}) \mathrm{O}_{2}+\mathrm{HO}_{2}$ reaction in the gas phase, Phys. Chem. Chem. Phys., 9, 3149-3162, 2007.

Karl, T., Guenther, A., Turnipseed, A., Tyndall, G., Artaxo, P., and Martin, S.: Rapid formation of isoprene photo-oxidation products observed in Amazonia, Atmos. Chem. Phys., 9, 7753-7767, doi:10.5194/acp-9-7753-2009, 2009.

Kleindienst, T. E., Lewandowski, M., Offenberg, J. H., Jaoui, M., and Edney, E. O.: Ozone-isoprene reaction: Re-examination of the formation of secondary organic aerosol, Geophys. Res. Lett., 34, L01805, doi:10.1029/2006GL027485, 2007.

Kroll, J. H., Ng, N. L., Murphy, S. M., Flagan, R. C., and Seinfeld, J. H.: Secondary organic aerosol formation from isoprene photooxidation, Environ. Sci. Technol., 40, 1869-1877, 2006.

Kubistin, D., Harder, H., Martinez, M., Rudolf, M., Sander, R., Bozem, H., Eerdekens, G., Fischer, H., Gurk, C., Klpfel, T., Knigstedt, R., Parchatka, U., Schiller, C. L., Stickler, A., Taraborrelli, D., Williams, J., and Lelieveld, J.: Hydroxyl radicals in the tropical troposphere over the Suriname rainforest: comparison of measurements with the box model MECCA, Atmos. Chem. Phys., 10, 9705-9728, doi:10.5194/acp-10-9705-2010, 2010.

Kwan, A. J., Chan, A. W. H., Ng, N. L., Kjaergaard, H. G., Seinfeld, J. H., and Wennberg, P. O.: Peroxy radical chemistry and $\mathrm{OH}$ radical production during the $\mathrm{NO}_{3}$-initiated oxidation of isoprene, Atmos. Chem. Phys. Discuss., 12, 2259-2302, doi:10.5194/acpd-12-2259-2012, 2012.

Lelieveld, J., Butler, T. M., Crowley, J. N., Dillon, T. J., Fischer, H., Ganzeveld, L., Harder, H., Lawrence, M. G., Martinez, M., Taraborrelli, D., and Williams, J.: Atmospheric oxidation capacity sustained by a tropical forest, Nature, 452, 737-740, doi:10.1038/nature06870, 2008.

Lin, Y.-H., Zhang, Z., Docherty, K. S., Zhang, H., Budisulistiorini, S. H., Rubitschun, C. L., Shaw, S. L., Knipping, E. M., Edgerton, E. S., and Kleindienst, T. E., Gold, A., and Surratt, J. D.: Isoprene epoxydiols as precursors to secondary organic aerosol formation: acid-catalyzed reactive uptake studies with authentic compounds, Environ. Sci. Technol., 46, 250-258, 2012.

Liu, Y. J., Herdlinger-Blatt, I., McKinney, K. A., and Martin, S. T.: Production of methyl vinyl ketone and methacrolein via the hydroperoxyl pathway of isoprene oxidation, Atmos. Chem. Phys. Discuss., 12, 33323-33358, doi:10.5194/acpd-12-33323-2012, 2012.

Lockwood, A. L., Shepson, P. B., Fiddler, M. N., and Alaghmand, M.: Isoprene nitrates: preparation, separation, identification, yields, and atmospheric chemistry, Atmos. Chem. Phys., 10, 6169-6178, doi:10.5194/acp-10-6169-2010, 2010.

Mao, J., Ren, X., Zhang, L., Van Duin, D. M., Cohen, R. C., Park, J.-H., Goldstein, A. H., Paulot, F., Beaver, M. R., Crounse, J. D., Wennberg, P. O., DiGangi, J. P., Henry, S. B., Keutsch, F. N., Park, C., Schade, G. W., Wolfe, G. M., Thornton, J. A., and Brune, W. H.: Insights into hydroxyl measurements and atmospheric oxidation in a California forest, Atmos. Chem. Phys., 12, 8009-8020, doi:10.5194/acp-12-8009-2012, 2012.

Napelenok, S. L., Pinder, R. W., Gilliland, A. B., and Martin, R. V.: A method for evaluating spatially-resolved $\mathrm{NO}_{\mathrm{x}}$ emissions using Kalman filter inversion, direct sensitivities, and spacebased $\mathrm{NO}_{2}$ observations, Atmos. Chem. Phys., 8, 5603-5614, doi:10.5194/acp-8-5603-2008, 2008.

Ng, N. L., Kwan, A. J., Surratt, J. D., Chan, A. W. H., Chhabra, P. S., Sorooshian, A., Pye, H. O. T., Crounse, J. D., Wennberg, P. O., Flagan, R. C., and Seinfeld, J. H.: Secondary organic aerosol 
(SOA) formation from reaction of isoprene with nitrate radicals $\left(\mathrm{NO}_{3}\right)$, Atmos. Chem. Phys., 8, 4117-4140, doi:10.5194/acp-84117-2008, 2008.

Orlando, J. J. and Tyndall, G. S.: Laboratory studies of organic peroxy radical chemistry: an overview with emphasis on recent issues of atmospheric significance, Chem. Soc. Rev., 41, 62946317, 2012.

Patchen, A. K., Pennino, M. J., Kiep, A. C., and Elrod, M. J.: Direct kinetics study of the product-forming channels of the reaction of isoprene-derived hydroxyperoxy radicals with NO, Int. J. Chem. Kinet., 39, 353-361, 2007.

Paulot, F., Crounse, J. D., Kjaergaard, H. G., Kroll, J. H., Seinfeld, J. H., and Wennberg, P. O.: Isoprene photooxidation: new insights into the production of acids and organic nitrates, Atmos. Chem. Phys., 9, 1479-1501, doi:10.5194/acp-9-1479-2009, 2009a.

Paulot, F., Crounse, J. D., Kjaergaard, H. G., Kurten, A., St. Clair, J. M., Seinfeld, J. H., and Wennberg, P. O.: Unexpected epoxide formation in the gas-phase photooxidation of isoprene, Science, 325, 730-733, doi:10.1126/science.1172910, 2009 b.

Paulot, F., Henze, D. K., and Wennberg, P. O.: Impact of the isoprene photochemical cascade on tropical ozone, Atmos. Chem. Phys., 12, 1307-1325, doi:10.5194/acp-12-1307-2012, 2012.

Paulson, S. and Seinfeld, J.: Development and evaluation of a photooxidation mechanism for isoprene, J. Geophys. Res., 97, 20703-20715, doi:10.1029/92JD01914, 1992.

Peeters, J. and Müller, J.-F.: $\mathrm{HO}_{\mathrm{x}}$ radical regeneration in isoprene oxidation via peroxy radical isomerisations. II: experimental evidence and global impact, Phys. Chem. Chem. Phys., 12, 1422714235, doi:10.1039/C0CP00811G, 2010.

Peeters, J., Nguyen, T., and Vereecken, L.: $\mathrm{HO}_{\mathrm{x}}$ radical regeneration in the oxidation of isoprene, Phys. Chem. Chem. Phys., 11, 5935-5939, doi:10.1039/b908511d, 2009.

Perring, A. E., Bertram, T. H., Wooldridge, P. J., Fried, A., Heikes, B. G., Dibb, J., Crounse, J. D., Wennberg, P. O., Blake, N. J., Blake, D. R., Brune, W. H., Singh, H. B., and Cohen, R. C.: Airborne observations of total $\mathrm{RONO}_{2}$ : new constraints on the yield and lifetime of isoprene nitrates, Atmos. Chem. Phys., 9, 14511463, doi:10.5194/acp-9-1451-2009, 2009a.

Perring, A. E., Wisthaler, A., Graus, M., Wooldridge, P. J., Lockwood, A. L., Mielke, L. H., Shepson, P. B., Hansel, A., and Cohen, R. C.: A product study of the isoprene $+\mathrm{NO}_{3}$ reaction, Atmos. Chem. Phys., 9, 4945-4956, doi:10.5194/acp-9-4945-2009, 2009b.

Pugh, T. A. M., MacKenzie, A. R., Hewitt, C. N., Langford, B., Edwards, P. M., Furneaux, K. L., Heard, D. E., Hopkins, J. R., Jones, C. E., Karunaharan, A., Lee, J., Mills, G., Misztal, P., Moller, S., Monks, P. S., and Whalley, L. K.: Simulating atmospheric composition over a South-East Asian tropical rainforest: performance of a chemistry box model, Atmos. Chem. Phys., 10, 279-298, doi:10.5194/acp-10-279-2010, 2010.

Ren, X., Olson, J. R., Crawford, J., Brune, W. H., Mao, J., Long, R. B., Chen, Z., Chen, G., Avery, M. A., Sachse, G. W., Barrick, J. D., Diskin, G. S., Huey, L.G., Fried, A., Cohen, R. C., Heikes, B., Wennberg, P. O., Singh, H. B., Blake, D. R., and Shetter, R. E.: $\mathrm{HO}_{\mathrm{x}}$ chemistry during INTEX-A 2004: Observation, model calculation, and comparison with previous studies, J. Geophys. Res., 113, 5310, doi:10.1029/2007JD009166, 2008.

Roberts, J. M. and Fajer, R. W.: UV absorption cross sections of organic nitrates of potential atmospheric importance and estima- tion of atmospheric lifetimes, Environ. Sci. Technol., 23, 945951, doi:10.1021/es00066a003, 1989.

Rollins, A. W., Kiendler-Scharr, A., Fry, J. L., Brauers, T., Brown, S. S., Dorn, H.-P., Dubé, W. P., Fuchs, H., Mensah, A., Mentel, T. F., Rohrer, F., Tillmann, R., Wegener, R., Wooldridge, P. J., and Cohen, R. C.: Isoprene oxidation by nitrate radical: alkyl nitrate and secondary organic aerosol yields, Atmos. Chem. Phys., 9, 6685-6703, doi:10.5194/acp-9-6685-2009, 2009.

Rosen, R. S., Wood, E. C., Wooldridge, P. J., Thornton, J. A., Day, D. A., Kuster, W., Williams, E. J., Jobson, B. T., and Cohen, R. C.: Observations of total alkyl nitrates during Texas Air Quality Study 2000: Implications for $\mathrm{O}_{3}$ and alkyl nitrate photochemistry, J. Geophys. Res., 109, D07303, doi:10.1029/2003JD004227, 2004.

Rowley, D. M., Lesclaux, R., Lightfoot, P. D., Noziere, B.,Wallington, T. J., and Hurley, M. D.: Kinetic and mechanistic studies of the reactions of cyclopentylperoxy and cyclohexylperoxy radicals with $\mathrm{HO}_{2}$, J. Phys. Chem., 96, 4889-4894, 1992.

Sander, R.: Compilation of Henry's Law constants for inorganic and organic species of potential importance in environmental chemistry, version 3, 1999.

Saunders, S. M., Jenkin, M. E., Derwent, R. G., and Pilling, M. J.: Protocol for the development of the Master Chemical Mechanism, MCM v3 (Part A): tropospheric degradation of nonaromatic volatile organic compounds, Atmos. Chem. Phys., 3, 161180, doi:10.5194/acp-3-161-2003, 2003.

Shepson, P. B., Mackay, E., and Muthuramu, K.: Henry's law constants and removal processes for several atmospheric $\beta$-hydroxy alkyl nitrates, Environ. Sci. Technol., 30, 3618-3623, 1996.

Singh, H. B., Brune, W. H., Crawford, J. H., Jacob, D. J., and Russell, P. B.: Overview of the summer 2004 intercontinental chemical transport experiment - North America (INTEX-A), J. Geophys. Res., 111, doi:10.1029/2006JD007905, 2006.

Sprengnether, M., Demerjian, K. L., Donahue, N. M., and Anderson, J. G.: Product analysis of the $\mathrm{OH}$ oxidation of isoprene and 1, 3-butadiene in the presence of NO, J. Geophys. Res., 107, 4268, doi:10.1029/2001JD000716, 2002.

Starn, T. K., Shepson, P. B., Bertman, S. B., White, J. S., Splawn, B. G., Riemer, D. D., Zika, R. G., and Olszyna, K.: Observations of isoprene chemistry and its role in ozone production at a semirural site during the 1995 Southern Oxidants Study, J. Geophys. Res., 103, 22425-22435, 1998.

Stavrakou, T., Peeters, J., and Müller, J.-F.: Improved global modelling of $\mathrm{HO}_{\mathrm{x}}$ recycling in isoprene oxidation: evaluation against the GABRIEL and INTEX-A aircraft campaign measurements, Atmos. Chem. Phys., 10, 9863-9878, doi:10.5194/acp-10-98632010, 2010.

Stavrakou, T., Müller, J.-F., Peeters, J., Razavi, A., Clarisse, L., Clerbaux, C., Coheur, P.-F., Hurtmans, D., De Mazière, M., Vigouroux, C., Deutscher, N. M., Griffith, D. W. T., Jones, N., and Paton-Walsh, C.: Satellite evidence for a large source of formic acid from boreal and tropical forests, Nat. Geosci., 5, 2630, doi:10.1038/ngeo1354, 2012.

Stone, D., Evans, M. J., Edwards, P. M., Commane, R., Ingham, T., Rickard, A. R., Brookes, D. M., Hopkins, J., Leigh, R. J., Lewis, A. C., Monks, P. S., Oram, D., Reeves, C. E., Stewart, D., and Heard, D. E.: Isoprene oxidation mechanisms: measurements and modelling of $\mathrm{OH}$ and $\mathrm{HO}_{2}$ over a South-East Asian tropical 
rainforest during the OP3 field campaign, Atmos. Chem. Phys., 11, 6749-6771, doi:10.5194/acp-11-6749-2011, 2011.

Surratt, J. D., Lewandowski, M., Offenberg, J. H., Jaoui, M., Kleindienst, T. E., Edney, E. O., and Seinfeld, J. H.: Effect of acidity on secondary organic aerosol formation from isoprene, Environ. Sci. Technol., 41, 5363-5369, 2007.

Surratt, J. D., Chan, A. W. H., Eddingsaas, N. C., Chan, M., Loza, C. L., Kwan, A. J., Hersey, S. P., Flagan, R. C., Wennberg, P. O., and Seinfeld, J. H.: Reactive intermediates revealed in secondary organic aerosol formation from isoprene, Proc. Natl. Acad. Sci., 107, 6640-6645, doi:10.1073/pnas.0911114107, 2010.

Taraborrelli, D., Lawrence, M. G., Crowley, J. N., Dillon, T. J., Gromov, S., Gross, C. B. M., Vereecken, L., and Lelieveld, J.: Hydroxyl radical buffered by isoprene oxidation over tropical forests, Nat. Geosci., 5, 190-193, 2012.

Thornton, J. A., Wooldridge, P. J., Cohen, R. C., Martinez, M., Harder, H., Brune,W. H.,Williams, E. J., Roberts, J. M., Fehsenfeld, F. C., Hall, S. R., Shetter, R. E., Wert, B. P., and Fried, A.: Ozone production rates as a function of $\mathrm{NO}_{\mathrm{x}}$ abundances and $\mathrm{HO}_{\mathrm{x}}$ production rates in the Nashville urban plume, J. Geophys. Res., 107, D124146, doi:10.1029/2001JD000932, 2002.

Treves, K., Shragina, L., and Rudich, Y.: Henry's law constants of some $\beta, \gamma$, and $\delta$ hydroxy alkyl nitrates of atmospheric interest, Env. Sci. Tech., 34, 1197-1203, 2000.

Tuazon, E. C. and Atkinson, R.: A product study of the gas-phase reaction of methacrolein with the $\mathrm{OH}$ radical in the presence of $\mathrm{NO}_{\mathrm{x}}$, Int. J. Chem. Kinet., 22, 591-602, 1990.

von Kuhlmann, R., Lawrence, M. G., Crutzen, P. J., and Rasch, P. J.: A model for studies of tropospheric ozone and nonmethane hydrocarbons: Model description and ozone results, J. Geophys. Res., 108, 4294, doi:10.1029/2002JD002893, 2003.

von Kuhlmann, R., Lawrence, M. G., Pöschl, U., and Crutzen, P. J.: Sensitivities in global scale modeling of isoprene, Atmos. Chem. Phys., 4, 1-17, doi:10.5194/acp-4-1-2004, 2004.

Warneke, C., de Gouw, J. A., Del Negro, L., Brioude, J., McKeen, S., Stark, H., Kuster, W. C., Goldan, P. D., Trainer, M., Fehsenfeld, F. C., Wiedinmyer, C., Guenther, A. B., Hansel, A., Wisthaler, A., Atlas, E., Holloway, J. S., Ryerson, T. B., Peischl, J., Huey, L. G., and Case Hanks, A. T.: Biogenic emission measurement and inventories determination of biogenic emissions in the eastern United States and Texas and comparison with biogenic emission inventories, J. Geophys. Res., 115, D00F18, doi:10.1029/2009JD012445, 2010.
Weaver, C. P., Cooter, E., Gilliam, R., Gilliland, A., Grambsch, A., Grano, D., Hemming, B., Hunt, S. W., Nolte, C., Winner, D. A., Liang, X.-Z., Zhu, J., Caughey, M., Kunkel, K., Lin, J.-T., Tao, Z., Williams, A., Wuebbles, D. J., Adams, P. J., Dawson, J. P., Amar, P., He, S., Avise, J., Chen, J., Cohen, R. C., Goldstein, A. H., Harley, R. A., Steiner, A. L., Tonse, S., Guenther, A., Lamarque, J.-F., Wiedinmyer, C., Gustafson, W. I., Leung, L. R., Hogrefe, C., Huang, H.-C., Jacob, D. J., Mickley, L. J., Wu, S., Kinney, P. L., Lamb, B., Larkin, N. K., McKenzie, D., Liao, K.-J., Manomaiphiboon, K., Russell, A. G., Tagaris, E., Lynn, B. H., Mass, C., Salathé, E., O’neill, S. M., Pandis, S. N., Racherla, P. N., Rosenzweig, C., and Woo, J.-H.: A preliminary synthesis of modeled climate change impacts on U.S. regional ozone concentrations, B. Am. Meteorol. Soc., 90, 1843-1863, doi:10.1175/2009BAMS2568.1, 2009.

Whalley, L. K., Edwards, P. M., Furneaux, K. L., Goddard, A., Ingham, T., Evans, M. J., Stone, D., Hopkins, J. R., Jones, C. E., Karunaharan, A., Lee, J. D., Lewis, A. C., Monks, P. S., Moller, S. J., and Heard, D. E.: Quantifying the magnitude of a missing hydroxyl radical source in a tropical rainforest, Atmos. Chem. Phys., 11, 7223-7233, doi:10.5194/acp-11-72232011, 2011.

Wu, S., Mickley, L. J., Jacob, D. J., Logan, J. A., Yantosca, R. M., and Rind, D.: Why are there large differences between models in global budgets of tropospheric ozone?, J. Geophys. Res., 112, D05302, doi:10.1029/2006JD007801, 2007.

Zhu, T., Barnes, I., and Becker, K. H.: Relative-rate study of the gas-phase reaction of hydroxy radicals with difunctional organic nitrates at $298 \mathrm{~K}$ and atmospheric pressure, J. Atmos. Chem., 13, 301-311, doi:10.1007/BF00058137, 1991. 